\title{
PUBLIC EXPENDITURE AND DEFICIT IN SPAIN $(1958-2014)^{*}$
}

Recibido: 12 de abril de 2016 • Aprobado: 22 de agosto de 2016

DOI: $10.22395 /$ seec.v19n40a1

Manuel Jaén-García ${ }^{* *}$

\section{ABSTRACT}

The objective of this study is to analyze a reduced model of the determinants of public spending growth from a demand side perspective. The model is based on the Buchanan and Wagner hypothesis but incorporates several other variables considered as determinants of public spending growth as well. The formulation of two different equations confirmed the influence of deficit on public spending growth during the period 1958-2014. This work provides two contributions to the analysis of public spending determinants in Spain. Firstly, the study period is considerably longer than that of others, and, secondly, unit root and cointegration analysis are used with breakpoints, which, to our knowledge, have not been previously utilized.

\section{KEY WORDS}

Public expenditure, gross domestic product, unit root, cointegration, break points.

\section{JEL CLASIFICATION}

H0O, H50, H62, E62

\section{CONTENT}

Introduction, 1. Public expenditure and deficit; 2. The model; 3. Empirical test of the model; 4. Summary and Conclusion; References, Appendix.

* This is an empirical study on determinants of public expenditure growth. This article is the product of the research project: "Determinants of public expenditure in Spain" carried out during the period 2014-2016 and financed by the Junta de Andalucía, Grupo de Investigación en Economía Aplicada from University of Almeria.

** Degree in Maths, University of Grenade, Grenade, Spain. Degree in Business and Economics, University of Malaga, Malaga, Spain. Ph. D. in Business and Economics, University of Grenade, Grenade, Spain. Professor of Applied Economics, Department of Business and Economics, University of Almeria, Almeria, Spain. Cañada de S/Urbano 04120 Almeria, Spain. Phone: +34950015197. E-mail: mjaen@ual.es. 


\section{GASTO PÚBLICO Y DÉFICIT FISCAL EN ESPAÑA (1958-2014) RESUMEN}

El propósito de este trabajo es analizar un modelo reducido de determinantes del crecimiento del gasto público desde el lado de la demanda. El modelo está basado en la hipótesis de Buchanan y Wagner pero se han añadido diversas variables que se consideran determinantes de demanda del gasto público. La formulación de dos ecuaciones diferentes confirma la influencia del déficit en el crecimiento del gasto público en el período 1958-2014. El trabajo aporta dos novedades al análisis de los determinantes del gasto público en España: por una parte, se extiende considerablemente el período objeto de estudio; por otra, se usa el análisis de raíces unitarias y cointegración con puntos de ruptura, que no ha sido utilizado anteriormente en este caso.

\section{PALABRAS CLAVE}

Gasto público, producto interior bruto, raíz unitaria, cointegración, puntos de ruptura.

\section{CLASIFICACIÓN JEL}

$\mathrm{H} 0 \mathrm{O}, \mathrm{H} 50, \mathrm{H} 62$, E62.

\section{CONTENIDO}

Introducción, 1. Gasto público y déficit; 2. El modelo; 3. Test empírico del modelo; 4. Conclusiones; Referencias, Anexos.

\section{GASTO PÚBLICO E DÉFICIT FISCAL NA ESPANHA (1958-2014) RESUMO}

O propósito deste trabalho é analisar um modelo reduzido de determinantes do crescimento do gasto público desde o lado da demanda. O modelo está baseado na hipótese Buchanan e Wagner mas se há adicionado diversas variáveis que se consideram determinantes de demanda do gasto público. A formulação de duas equações diferentes confirma a influência do déficit no crescimento do gasto público no período 1958-2014. O trabalho aporta duas novidades à análise dos determinantes do gasto público na Espanha. Por uma parte se estende consideravelmente o período objeto de estudo. Por outra se usa a análise de raízes unitárias e co-integração com pontos de ruptura que não há sido utilizado anteriormente neste caso.

\section{PALAVRAS CHAVE}

Gasto público, produto interno bruto, raiz unitária, co-integração, pontos de ruptura.

\section{CLASSIFICAÇÃO JEL}

H0O, H50, H62, E62.

\section{CONTEÚDO}

Introdução, 1. Gasto público e déficit; 2. O modelo; 3. Test empírico do modelo; 4. Conclusões; Referências, Anexos. 


\section{INTRODUCTION}

Following the studies of Niskanen (1978), economic literature received different tests of Buchanan and Wagner's hypothesis. Said hypothesis states that public deficit increases expenditure as it reduces the tax price perceived by current tax-payers of public services, thus increasing demand for these services.

Numerous tests of this hypothesis have been conducted for different countries: Niskanen (1978) studied the relationship for USA, Khan (1988) for Pakistan, Craigwell (1991) for small open economies of Barbados, Tridimas (1992) and Asworth (1995) used data from the United Kingdom, Provopoulos (1982), Hondroyiannis and Papapetrou (2001) and Christopoulos and Tsionas (2003) worked with data for Greece, Courakis, Roque-Moura, and Tridimas (1993) for Greece and Portugal, and Yay (2009) studied data for Turkey. As for Spain, this test has been carried out by Raymond and Gonzalez-Páramo (1988) and Jaén (1999). In general terms, the results of the above studies favour the Buchanan- Wagner hypothesis.

In the case of the present study, we analyze a reduced model of the determinants of public spending growth from a demand side perspective. The model is based on the B-W hypothesis but incorporates several other variables considered, both theoretically and empirically, as determinants of public spending growth. This extension of the work allowed us to analyze the possible of validation of Wagner's Law and the Baumol disparity hypothesis, which are normally formulated in bivariant models. The formulation of two different equations confirmed the influence of deficit on public spending growth but produced different conclusions in the cases of income, relative prices and population.

In this essay we apply the methodology of unit root and co-integration in time series to make this contrast. On the one hand, this approach allows the elimination of possible problems of spurious regressions that can appear when variables are expressed in levels. On the other hand, it also makes it possible to formulate an error correction mechanism associated with co-integration vector, which provides the dynamic of a short run model. The study period considered in Spanish economics ${ }^{1}$ was 1958-2014 -a period which saw many economic and social changes in the country. To take said changes into consideration, we allow multiple structural breaks in the unit-root and cointegration testing procedures of the series considered.

We obtain two conclusions:

a) In the first equation, we obtain that deficit increases government spending. The coefficient estimated for the income elasticity is positive with a value very close

We don't have data for a longer period 
to the unit, which indicates, in line with Wagner's Law, that a rise in income increases government spending. In the case of relative prices, the value obtained is positive, contradicting the Baumol production disparity hypothesis. Finally, the fact that the population coefficient value is less than 1 suggests economies of scale in public spending as population increases.

b) As regards the second equation, the results obtained are slightly different. The elasticity of public spending is approximately equal to 1 , which confirms the B-W hypothesis. Moreover, the income has an elasticity less than 1, which means Wagner's Law is not accepted. Finally, the Baumol disparity hypothesis is validated as it predicts that the relative prices coefficient is negative.

The remainder of this study is divided into five sections. The first section details the information available on expenditure and public deficit evolution during the 19582014 period. In the second, we formulate the model, and in the third, we conduct the empirical test using data from the Spanish economy. Finally, in the fourth, a summary is provided which is then followed by corresponding conclusions.

\section{PUBLIC EXPENDITURE AND DEFICIT}

Recently, Spanish public expenditure has experienced sharp growth in both current prices as well as real prices, and GDP percentages and absolute values.

During the 1958-2014 period, which is being studied in this work, three distinct phases can be identified according to their nature with respect to public expenditure in Spain. The first phase spans from 1958 to 1975, a time in which public expenditure, in real prices, was less than $25 \%$ of GDP ${ }^{2}$. Public spending in the Spanish economy in the first part of this period was very low.

State intervention in the economy was carried out through regulation, which came in the form of laws and statutes. In the 1960's, industrialisation helped increase public expenditure. In true Wagner fashion, economic development went hand in hand with an increase in population, urbanisation, housing, education, health and redistribution of revenue.

During the second period, between 1976 and 1985, a rapid expansion of public spending took place in Spain ${ }^{3}$. These expenditures increased from 23,19\% of GDP to $42,5 \%$, in line with countries in the OECD, whose average spending represented

2 Gross Domestic Product.

3 Following the constitution passed in 1978, a decentralization of the political structure in Spain takes place accompanied by the gradual transition of powers to its various regions (called Autonomous Communities, A.C.) At present, the A.C. possess the most important powers, which relate to aspects that generate the larg- 
47\% of GDP. Scholars concur that the fundamental driving forces behind this growth in public spending during that time were: 1) the transition to the democracy that produced a boom in demand for social rights, which had previously been withheld by the Franco regime, 2) economic crisis forced enterprises to acquire state grants or capital transfer, 3) the persistence of the budget deficit and its new financing according to market conditions, 4) the decentralization of certain spending auspices without yielding any corresponding fiscal responsibility to the Spanish Autonomous Regions. Also during this time, a tremendous increase in unemployment occurred as a result of the economic recession. In order to mitigate the threat of mass layoffs, an initiative was established that offered the possibility of early retirement.

In the third period, between 1986 and 1993, spending grew as a consequence of the socialist government policy for the Welfare State 4 . National health cover increased, as did the number of pensioners under the non-tax paying regime and the quantity of their benefits. The rise in pupils in compulsory and vocational education programmes caused education expenditure to increase as well. Similarly, the agreement with private education institutions, which entitled them to receive state subsidies, also caused this spending to jump. In this period of consolidation of Spanish Autonomous Communities, a notable increase in expenditure was implemented by the State but this caused a significant deterioration of the budget balance. Towards the end of this period, the absolute necessity to meet the requirements established by the Maastricht Agreement produced a reduction in the deficit when this had just reached its highest value, 5,9\% in relation to GDP in 1993.

Between 1994 and 1998 a drastic change took place in the public sector in Spain. The basic reasons for this switch can be found in the need to meet the conditions of both the Maastrich Agreement and the Stability and Growth Pact, in conjunction with the fact that this period coincided with the beginnings of the ascending phase of the economic cycle in 1996. Elevated budget deficits (7,3\% of GDP in 1994) dropped to 2,6\% in 1998, strictly complying with the condition of the Stability Pact (3\% of GDP).

The period between 1999 and 2007 represented a period of consolidation of public finances in Spain, which was primarily based on the real estate bubble that made possible the unprecedented growth of the Spanish economy. Given this new economic setting, a balanced budget was achieved in 2001 with public spending

est part of public expenditure, such as healthcare and education. However, the collection and redistribution of tax income still remains in the hands of the central government.

4 Welfare State uses public expenditure to make income redistribution. It is guaranteed minimum incomes to the citizen as well as an improvement of education and health. 
at $40 \%$ of GDP while a $4 \%$ rise in GDP also took place with respect to the previous period (1997-2001).

From 2007 to 2014 an implosion of the Spanish economy occurred; this was sparked by the bursting of the real estate bubble. At first, expansion continued and the Spanish GDP reached the EU 27 average. As of that moment the Spanish economy, caught in the wake of American and European economies and its own internal problems, entered a severe recession from which it began to emerge in 2014 with some positive GDP growth, albeit modest, $(0,08 \%)^{5}$ and with elevated budget deficits (3,5\% of GDP in 2013 and 2,5\% of GDP in 2014).

Even though contemporary Spanish public expenditure is vastly increasing there is a difference with respect to the rest of the OECD European countries. In 1960, the ratio with regards to GDP was 19,8\% in Spain whilst in other European Countries it was $19,5 \%$. Out of the total OECD, the average was $26,6 \%$. In less than thirty years the respective ratios were EU (27) 46,1\%, EU (15) 50,9\%, and OCDE 41,1. Now, 2014, the ratios are E.U. (27) 48,1\%, E.U. (15) 49,2\%, OCDE 41,2\% and Spain 43,6\%.

In Graph 1, we observe the evolution of expenditure in percentages of GDP for both current and real prices. Three stages can be quantified. In current prices, in 1958 the expenditure was $12,54 \%$ of GDP while in 1974 that percentage was $21,45 \%$.

Graph $1^{6}$. Public expenditure/Gross domestic product current and real prices

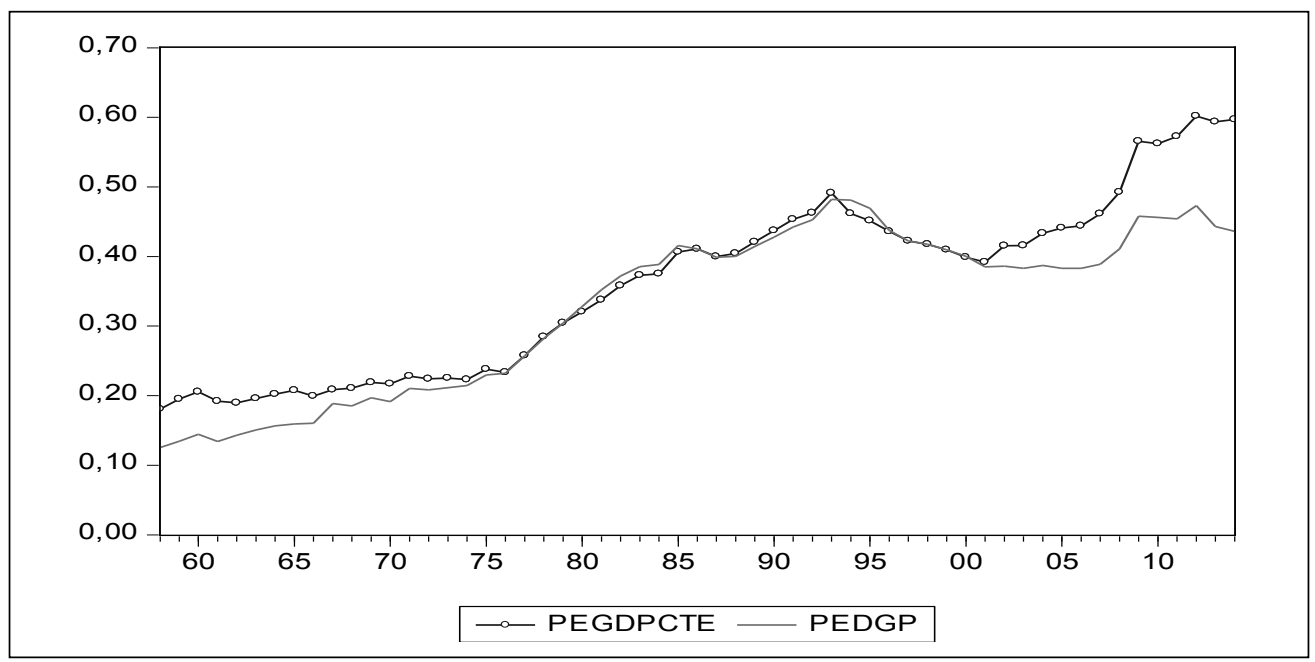

Source: Author's elaboration

5 The data are taken from the General State Comptroller of the Treasury Department (IGAE, in Spanish).

6 PEDGP: Public expenditure/gross domestic product. PEDGPCTE: PEcte/DGPcte 
Over a period of sixteen years, total expenditure increased by $8,89 \%$, thus indicating an annual average increase of 0,56 points.

In 1975, public expenditure was 22,95\% of GDP against the $36,9 \%$ in 1982, thus revealing a $14 \%$ rise, an average annual increase of 1,75 points.

In 1995, it increased to $46,92 \%$ of GDP, or 0,72 points on average. The highest value registered, in percentage terms, is seen in 1992 when it reaches $48 \%$ of GDP. Due to the need to meet the conditions of the Maastrich Pact, it was not until 1997 when a strong decrease in public spending took place, and in 1998 it had dropped to $42 \%$ of GDP. In the years that followed, the need to comply with the Stability and Growth Pact drove the Spanish public sector to its lowest levels since 1980 with public spending in 2006 reaching 38,3\% of GDP. The recession in the years to come caused public spending to rise (among other expenditures, there was a conversion of private banking debt into a public sector expenditure), recently placing it at $47,13 \%$ of GDP in 2013 and 43,6\% of GDP in 2014.

If we consider expenditure as well as GDP in real prices, we can verify that a part of that increase is due to price effect. As many authors, between others Beck (1976, 1981), state government expenditure has a tendency to be overestimated when it is measured at current prices, provided that output growth rate is lower in the public sector due to inherent qualities of public output.

We obtain a better view of that increase if government expenditure is deflated by its own implicit deflator.

At real prices public expenditure in 1958 represented 18,08\% of GPD as opposed to $22,31 \%$ in 1974 , revealing an increase of $5,17 \%$ rather than the $8,89 \%$ found previously. We can attribute 3,72 points of increase, that is to say a $41,8 \%$, to the price effect. In 1975, in real terms, expenditure represented 23,75\% of GDP while in 1982 the percentage was $35,52 \%$. Consequently, the increase would be $11,74 \%$, therefore, we can attribute 2,26 points to price effect. In 1995, in real prices, expenditure represented $45,1 \%$ of GDP, with an increase of 9,32\% in the 82-95 period. Given that in current prices the increase was $10,02 \%$, we can attribute 0,7 points to the price effect. In 1996, in real prices, expenditure represented 43\% of GDP, and 43,6\% in 2014.

Even though the most significant increase in public deficit occurred after 1975, Fuentes and Barea (1996) believe that in Spanish finance there is a historical trend of public deficit which lies in the strict nature of the fiscal system and the impossibility of financing vast public expenditures when citizen requirements increase with only a minimum level of tax revenue. Graph 2 shows evolution of public deficit in the period 1958-2014 


\section{Graph 2. Public deficit in Spain 1958-2014}

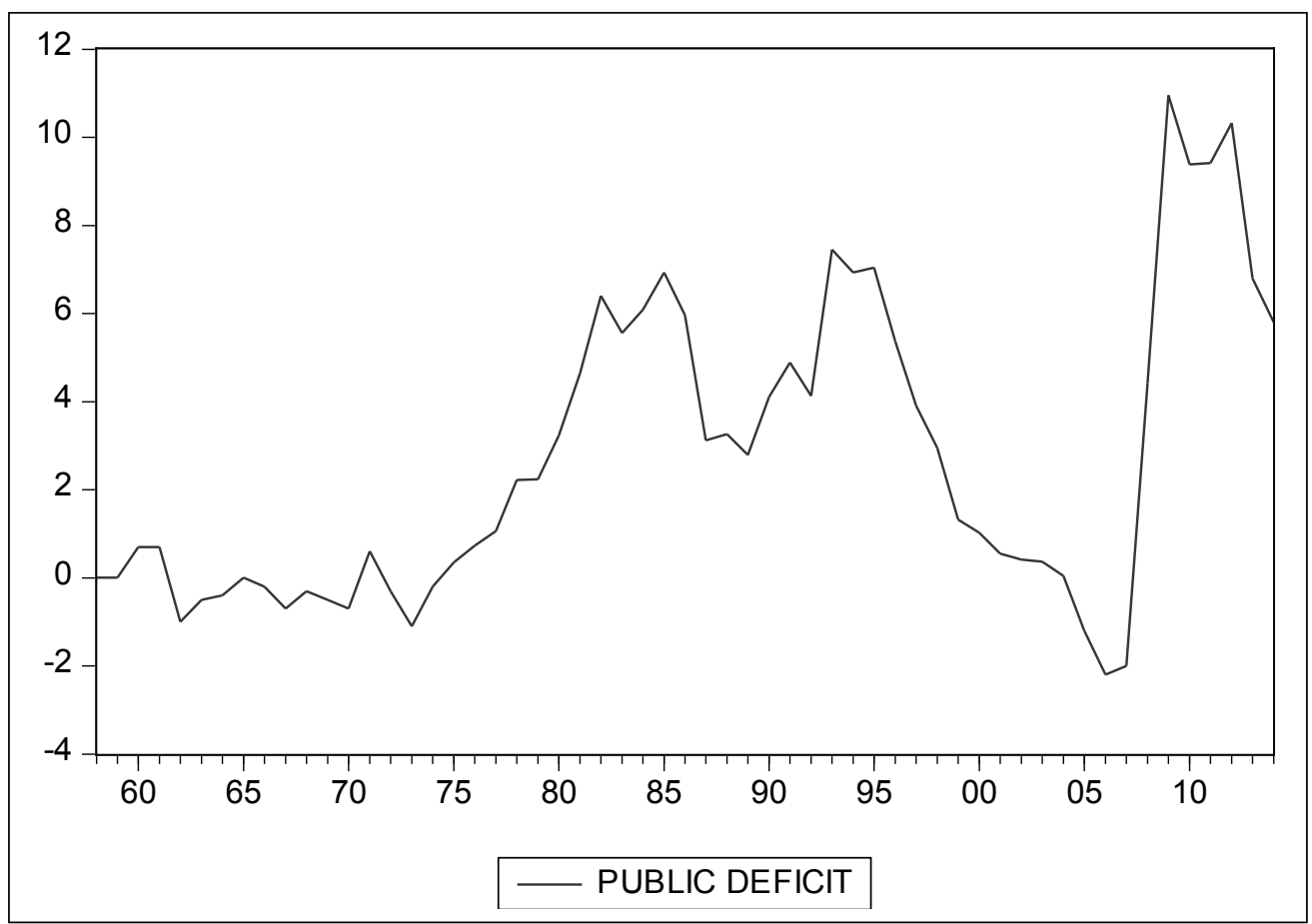

Source: Author's elaboration

In line with Serrano (1999), there have been three distinct phases in the evolution of deficit in recent years. Increase in deficit had been continuous until 1985. This was caused by a weak government and measures by the opposition of the PSOE who fostered a substantial growth in expenditure and deficit in order to alleviate the economic crisis.

This situation continued in the early years of the socialist government. In the fourth year, the situation improved after Spain's admission into the European Community and economic recovery thanks to a favourable period of time in Europe, although the deficit was not completely eliminated.

Between 1990 and 1993 an increase in social expenditure, which was fundamentally brought about by the general strike and the investments in infrastructures for the Olympic Games and Expo'92, in conjunction with its own accrued debt and economic change. In recent years the signing of the Maastricht Agreement meant having to reduce the deficit in order to comply with the entry requirements of the EMU (European Monetary Union). This forced the government to reduce the deficit, which reached a value of 2,9\% of GDP in 1998. From 1999 to 2014 there was a period 
of decline with fiscal surplus from 2005 to 2008. Later, the economic crisis constituted a new period of deficit, reaching the maximum in 2012 with 10,32\% of GDP.

From a financial point of view, Serrano (1999) and Hernández (1996) identifies two main phases.

Firstly, in matters of finance, the Spanish Central Bank was highly exploited as a resource, and the resources of the financial system were not accessible because of investment ratio. This constituted an inexpensive system, but it interfered with monetary control and also the fight against inflation. This had a negative impact on the efficient distribution of bank credit, mainly due to the goal of maintaining privileged channels of financing for the public sector, thus altering all other prices.

Secondly, since mid-1984, deficit is financed by capital market sources thanks to public debts policy. Essentially, debt is managed by a treasurer with tools to ensure suitable finance of public deficit to permit lower costs. This system has the advantage of not directly affecting monetary policy, however, it produces a lack of finance in the economy as a whole.

\section{THE MODEL}

Among the various explanations for the increase in public expenditure, the most renown is Buchanan and Wagner's $(1977)^{7}$ hypothesis.

According to this hypothesis, budget deficits allow for a higher level of expenditure. Its proposition lies on the premise that public deficits reduce the perceived prices of goods and services provided to the current generation of voters, which, in turn, increases the demand for such social services ${ }^{8}$.

Niskanen (1978) considers that budget deficit will reduce the perceived prices of federal services by current generations of voters as long as one or a combination of the three conditions is met:

1) Voters are unaware of the future tax liabilities due to current deficits.

2) Voters discount this future tax liability at a higher rate than the interest rate on public debt.

7 Borcherding (1985) says Buchanan and Wagner published a provocative book titled "Democracy in Deficit: Political Legacy of Keynes" in which it was said that the public acceptance of Keynes's paradigm helped to finance deficit and increase public expenditure".

8 They consider that Keynes's macroeconomic theory provides a legitimate justification for the State incurring annual deficits that reduce apparent price of public services in relation to a private service provision for the current generation of taxpayers. Consequently, public service supply (and government expenditure) increases as debt affects future generations of taxpayers. 
3) Voters have finite lives, and they value the future tax liability during their life more than the liability of subsequent generations.

Once these three conditions are satisfied and there is a negative elasticity of demand of governmental services regarding the perceived tax price, government expenditure will increase.

The model considered in the present study is based on Niskanen (1978), Raymond and Gonzalez-Páramo (1988), Asworth (1995) and Jaén (1999).

Initially, we take the function of the average taxpayer-voter's demand for government services based on the approximation developed by Borcherding and Deacon (1972) and Bergstrom and Goodman (1973)

$$
\mathrm{L} n \mathrm{Q}=\alpha+\beta \mathrm{L} n \mathrm{~T}+\gamma \mathrm{L} n \mathrm{~V}^{9}
$$

$\mathrm{Q}$ is the amount of government services consumed by the average voter, $\mathrm{T}$ is the tax price perceived by the aforementioned average taxpayer-voter and $\mathrm{V}$ is the latter's income.

$\mathrm{Q}$ is not directly observable, however, the $\mathrm{OC}$ product would give us public expenditure per taxpayer with $C$ being unit cost of government services. ${ }^{10}$

Meanwhile, QCN product gives us total public expenditure with $\mathrm{N}$, the total population. If $\mathrm{G}=\mathrm{QCN}$, the result is:

$$
\mathrm{L} n \mathrm{G}=\alpha+\beta \mathrm{L} n \mathrm{~T}+\gamma \mathrm{L} n \mathrm{~V}+\mathrm{L} n \mathrm{C}+\mathrm{L} n \mathrm{~N}
$$

$\mathrm{T}$ is equal to $\mathrm{CF}$ product; $\mathrm{C}$ is unit cost of government services and $\mathrm{F}$ represents the tax participation in government services paid by the average taxpayer-voter. Likewise, the unit tax participation $\mathrm{F}$ is the total fraction of public expenditure and $\mathrm{G}=\mathrm{QCN}$ paid by taxpayer $\mathrm{I}$. That means $\mathrm{F}=(\mathrm{I} / \mathrm{G})(1 / \mathrm{N})^{11}$. If total income is considered rather than per capita income $\mathrm{Y}=\mathrm{VN}$, the result is

$9 \quad$ Niskanen (1978) and Raymond and González-Páramo (1988) consider a variable representing autonomous influences, which affects the demand of government services. In our case we have preferred to concentrate only on the elements of demand theory of the model.

10 After studying Niskanen's model (1978), it is supposed that $\theta=1$ in $Q=G / C \cdot 1 / N^{\theta}$. $\theta$ means degree of privacy (or publicity) of public services, $\theta=0$ means that goods are totally public; if cost is proportional to the population, it will be the unit and if there is an exclusion effect in the unit cost of the services performed by public sector, it will be 1 . When $\theta=0$, unit cost is invariant to the number of taxpayers to whom these services are supplied. Economies of scale emerge in the provision of government services when the coefficient is less than zero. The general consensus is that the degree of publicity coefficient is approximately unit, thus indicating that the goods and services provided by government are private in nature.

11 We follow to Niskanen (1978) to suppose that the tax participation is the same for everybody. 


$$
\mathrm{LnG}=\alpha+\beta \operatorname{Ln}\left(\frac{\mathrm{I}}{\mathrm{G}}\right)+(1+\beta) \operatorname{LnC}+\gamma \operatorname{LnY}+(1-\beta-\gamma) \mathrm{Ln}
$$

Following to Tridimas (1992) and Courakis, Roque-Moura, and Tridimas (1993) we use adequate deflators for the different variables, that is to say, we deflate total government expenditure by its unit cost C; total income (GDP) by its deflator P and we use $\mathrm{C} / \mathrm{P}$ ratio as the appropriate price variable in the regression equation. The result is

$$
\operatorname{Ln}\left(\frac{\mathrm{G}}{\mathrm{C}}\right)=\alpha+\beta \operatorname{Ln}\left(\frac{\mathrm{I}}{\mathrm{G}}\right)+\beta \operatorname{L} n\left(\frac{\mathrm{C}}{\mathrm{P}}\right)+\gamma \mathrm{Ln} \mathrm{Y}+(1-\beta-\gamma) \mathrm{Ln} \mathrm{N}
$$

Or, if restrictions set within parameters ${ }^{12}$ are left aside and time consideration is introduced in the model

$$
\operatorname{Ln}\left(\frac{\mathrm{G}}{\mathrm{C}}\right)_{t}=\tau_{0}+\tau_{1} \operatorname{Ln}\left(\frac{\mathrm{I}}{\mathrm{G}}\right)_{t}+\tau_{2} \operatorname{Ln}\left(\frac{\mathrm{C}}{\mathrm{P}}\right)_{t}+\tau_{3} \operatorname{Ln} \mathrm{Y}_{t}+\tau_{4} \mathrm{LnN}_{t}
$$

In this equation $\tau_{1}$ measures the impact of the finance deficit; $\tau_{2}$ and $\tau_{3}$ measure the respective price and income elasticity ${ }^{13}$ and $\tau_{4}$ is a mixture between the degree of publicity about government spending, the price elasticity and income elasticity and reflects personal preferences.

It is expected that coefficients $\tau_{1}$ and $\tau_{2}$ are negative as opposed to $\tau_{3}$ and $\tau_{4}$, which must be positive.

Similar to the previous model, some authors such as Niskanen (1978), Provopoulos (1982), Craigwell (1991), Hondroyiannis and Papapetrou (2001) Christopoulos and Tsionas (2003), among others ${ }^{14}$, consider that the unit cost of the bundle of cost services, $C$, is not measurable but can be a function of the average salary rate in the private sector (Wages) and the number of voters. That is:

$$
\mathrm{LnC}=\delta+\lambda \mathrm{LnW}+\mu \mathrm{Ln} \mathrm{N}
$$

If the coefficient $\lambda$ is positive, the productivity growth rate in the public sector is lower than in the private sector. If $\lambda$ is zero, there is no productivity growth, and if it is negative, productivity in the public sector is greater than in the private sector. The $\mu$ coefficient estimates to what extent the government services are "public". If it is equal to zero, the government services are considered to be pure public goods,

\footnotetext{
12 Validity of these restrictions is contrasted on $4^{\text {th }}$ item

13 If $\tau_{3}>1$ we will have an indirect check of Wagner's Law. View Jaén (2011)

14 Yay and Tastan (2009) use a more simple equation.
} 
and if it is equal to one, their cost is proportional to the number of tax-payers/voters. And, if it is greater than the unit, there is a crowding-out effect of government services, while if it is negative, there will be economies of scale in the provision of government services.

Starting with Equation (3), and making substitutions with Equation (6) we obtain

$$
\mathrm{Ln}\left(\frac{\mathrm{G}}{\mathrm{C}}\right)=\varphi_{0}+\varphi_{1} \mathrm{Ln}\left(\frac{\mathrm{I}}{\mathrm{G}}\right)+\varphi_{2} \mathrm{~L} n \mathrm{Y}+\varphi_{3} \mathrm{~L} n\left(\frac{\mathrm{W}}{\mathrm{P}}\right)+\varphi_{4} \mathrm{~L} n \mathrm{~N}
$$

where $\phi_{0}=\alpha+(1+\beta) \delta \phi_{1}=\beta \phi_{2}=\gamma \phi_{3}=(1+\beta) \lambda \phi_{4}=(1+\beta) \mu+1-\beta-\gamma$

\section{EMPIRICAL TEST OF THE MODEL}

If Models ( 5 and 7 ) are expressed in levels, there is a risk of producing a spurious regression. In contrast, the model in first differences, despite all likelihood that it obtains stationarity, omits all information in the long-term ${ }^{15}$. The empirical analysis has to be carried out carefully to verify the nature of the series because if they are not stationary, problems could arise in the estimation of the regression equation coefficients. Valid estimations for the two models require that data be stationary (integrated zero-order) or, if they are not stationary (integrated first-order), they must be cointegrated. More specifically, the first step will be to verify whether the variables are stationary or whether they have one or more unit roots. If they are integrated, an analysis will be made to verify the possible existence of cointegration between them. If they are cointegrated, the relationships or cointegration equations will be estimated. These cointegration equations specify the long-run relationships between the variables. Given the long period of time studied, it is possible to find instances of structural change in the series. For this reason, we allow structural breaks in the series in both the unit root and cointegrating tests. In this view Jaén and Molina (1997, 1999); Asworth (1995); Priesmeier and Koester (2012); Kuckuck, (2014). These structural breaks may be the result of changes in the economy or in the different factors that affect or determine the series utilized. In this situation, if the structural changes are not taken into consideration when the existence of a long-term relationship is investigated, said relationship might not be detected when it does indeed exist.

\footnotetext{
15 Many macroeconomic time series are not stationary and they stimulate a stochastic process rather than a determinist one. Non-stationarity produces many econometric problems: relations of spurious regression are very likely in the levels of macroeconomic variables as well as the possibility of generating inconsistent parameters of OLS regressions, unless the variables considered are cointegrated.
} 
Following Tridimas (1992); Craigwell (1991); Asworth (1995) and in order to consider the differences between the short and long-term responses to demand the most suitable option is to adopt a vector error correction model for Equation 5.

$$
\begin{aligned}
& \Delta \operatorname{Ln}((\mathrm{G} / \mathrm{C}))_{-} t=\varphi_{-} 0+\varphi_{-} 1 \Delta \operatorname{Ln}((\mathrm{I} / \mathrm{G}))_{-} t+\varphi_{-} 2 \Delta \operatorname{Ln}((\mathrm{C} / \mathrm{P}))_{-} t+\varphi_{-} 3 \Delta \mathrm{LnY}{ }_{-} t+ \\
& \varphi_{-} 4 \mathrm{LnN} \mathrm{N}_{-} t+\mu\left[\operatorname{Ln}(\mathrm{G} / \mathrm{C})_{-}(t-1)-\varphi_{-} 5 \mathrm{Ln}(\mathrm{I} / \mathrm{G})_{-}(t-1)-\varphi_{-} 6 \operatorname{Ln}(\mathrm{C} / \mathrm{P})_{-}(t-1)\right. \\
& \left.-\varphi_{-} 7 \mathrm{LnY}{ }_{-}(t-1)-\varphi_{-} 8 \mathrm{LnN} \mathrm{N}_{-}(t-1)-\varphi_{-} 9\right]
\end{aligned}
$$

It avoids the problem of spurious regression because the term

$$
\operatorname{Ln}\left(\frac{\mathrm{G}}{\mathrm{C}}\right)_{t-1}-\varphi_{5} \operatorname{Ln}\left(\frac{\mathrm{I}}{\mathrm{G}}\right)_{t-1}-\varphi_{6} \operatorname{Ln}\left(\frac{\mathrm{C}}{\mathrm{P}}\right)_{t-1}-\varphi_{7} \mathrm{LnY}_{t-1}-\varphi_{8} \mathrm{LnN}_{t-1}-\varphi_{9} \quad[9]^{16}
$$

Is the error correction measurement, that is to say, the long term. That would make the terms in first differences the drifts in the short-term of this long term.

If it is shown that (9) is a cointegration vector, the error correction mechanism gives us the short-term dynamic. In this way, the problems of spurious regression can be avoided and a long-term relationship can be established between expenditure increase and budget deficit. In the same manner, an appropriate methodology can be utilized to carry out the tests in both the short-term and long-term.

Logically, the first step is to establish the integration order of the different time series that specify model variables. This is done through different unit-root tests: Dickey-Fuller (DF or ADF) and Phillips-Perron (PP) among others.

Once the integration order of variables is established, a test can be conducted to determine whether there is a long-term relationship among some or all the variables using the method suggested by Johansen (1991) and Johansen and Juselius (1990, 1992) to test the existence of a cointegration vector. Finally, an additional goal is to find the error correction model corresponding to the cointegration vector mentioned in the previous point.

The variables used in the estimation are the following: price index of government expenditures, $\mathrm{C}$ is defined as a weighted average of deflators of components of total government expenditure, $G$ is total government expenditure; $G / C$ is total government expenditure deflated by the previous price index; relative price, $\mathrm{C} / \mathrm{P}$ is ratio of price index of government expenditure divided by implicit GDP deflator; real income $\mathrm{Y}$ is measured as GDP to constant price; I is government tax revenue and $\mathrm{N}$

16 We can use the same approach for the second equation 
is total population ${ }^{17}$. In the second equation, $\mathrm{Ln} \mathrm{C} / \mathrm{P}$ is replaced by $\mathrm{Ln} \mathrm{W} / \mathrm{P}$, where $\mathrm{W}$ is annual average wage to constant prices.

In Table 1, the data are the results of applying different unit root tests to representative series of variables of the model. It is observed that all the series are order one integrated I(1).

\section{Table 1. Unit root test ${ }^{18}$}

\begin{tabular}{|c|c|c|c|c|c|c|c|c|c|c|}
\hline Serie & ADF test & $\begin{array}{c}\text { ADFGLS } \\
\text { test }\end{array}$ & PP test & $\begin{array}{c}\text { KKPSS } \\
\text { test }\end{array}$ & ERS test & $\begin{array}{c}\text { NP test } \\
\text { MZa }\end{array}$ & $\begin{array}{c}\text { NP test } \\
\text { MZ1 }\end{array}$ & $\begin{array}{c}\text { NP test } \\
\text { MSB }\end{array}$ & $\begin{array}{c}\text { NP test } \\
\text { MPT }\end{array}$ & SP test \\
\hline LnG/C & $-0,54^{*}$ & $-0,73^{*}$ & $-0,22^{*}$ & $0,23^{*}$ & $64,40^{*}$ & $-2,35^{*}$ & $-0,81^{*}$ & $0,34^{*}$ & $28,07^{*}$ & $-0,78^{*}$ \\
\hline Ln I/G & $-2,92^{*}$ & $-2,89^{*}$ & $-2,47^{*}$ & $0,13^{*}$ & $5,51^{*}$ & $-16,81^{*}$ & $-2,89^{*}$ & $0,17^{*}$ & $5,47^{*}$ & $-2,16^{*}$ \\
\hline Ln Y & $-2,26^{*}$ & $-1,90^{*}$ & $-0,43^{*}$ & $0,18^{*}$ & $36,65^{*}$ & $-9,49$ & $-1,94$ & $0,20^{*}$ & $10,54^{*}$ & $-0,98^{*}$ \\
\hline Ln C/P & $-0,42^{*}$ & $-0,41^{*}$ & $1,15^{*}$ & $0,23^{*}$ & $136,98^{*}$ & $-1,23^{*}$ & $-0,49 *$ & $0,39^{*}$ & $37,55^{*}$ & $-0,89^{*}$ \\
\hline Ln N & $-3,33^{*}$ & $-2,88^{*}$ & $-1,84^{*}$ & $0,11^{*}$ & $2,08^{*}$ & $-55,58$ & $-5,26$ & $0,09^{*}$ & 1,65 & $-0,86^{*}$ \\
\hline Ln W/P & $-1,09^{*}$ & $-1,58^{*}$ & $-1,56^{*}$ & $0,23^{*}$ & 246,93 & $-1,53$ & $-0,67$ & 0,44 & 41,08 & $-0,68^{*}$ \\
\hline
\end{tabular}

\section{Source: Author's elaboration}

None of the tests reject the null hypothesis of a unit root in time series ${ }^{19}$. Utilizing the graph $\mathrm{s}^{20}$, all the tests are calculated including a constant and a trend in the test equation ${ }^{21}$ : The lags number for ADF was calculated using SIC. The bandwidth for the PP and KPSS test is selected based on Newey-West using Bartlett Kernell.

17 The data have been collected from the General State Comptroller (IGAE in Spanish), the National Statistics Institute (INE) and the Valencian Economic Research Institute (IVIE). The database used in the research is available for any researcher who requests through the e-mail: mjaen@ual.es.

18 The tests used were: Augmented Dickey-Fuller (ADF), Phillip-Perron (PP), Kwiatkowski, Phillips, Schmidt and Shin (KPSS), Elliot, Rothenberg and Stock (1996) point optimal (ERS), Ng-Perron (NP) and Schmidt and Phillips (1992).

19 Null hypothesis in the KKPS test is that the series is stationary

20 View appendix graphs

$215 \% \mathrm{VC}$ ADF -3,49; DFGLS -3,17; PP = -3,49; KPSS = 0,146; ERS = 5,71; NP = -17,9, -2,91, 0,168, 5,48;

$\mathrm{SP}=-3,06$ 
For ERS and NgP we used Spectral OLS based on SIC. The symbols *, ${ }^{* *}$ and ${ }^{* * *}$ indicate significance at 1\%,5\%, and 10\% using critical values from MacKinnon (1991), KPSS (1992), ERS (1996), NgP (2001) and Schmidt and Phillips (1992).

Table 2. Unit root test for the first differences of the time series

\begin{tabular}{|c|c|c|c|c|c|c|c|c|c|c|}
\hline Serie & ADF test & $\begin{array}{c}\text { ADFGLS } \\
\text { test }\end{array}$ & PP test & $\begin{array}{c}\text { KKPSS } \\
\text { test }\end{array}$ & ERS test & $\begin{array}{c}\text { NP test } \\
\text { MZa }\end{array}$ & $\begin{array}{c}\text { NP test } \\
\text { MZ1 }\end{array}$ & $\begin{array}{c}\text { NP test } \\
\text { MSB }\end{array}$ & $\begin{array}{c}\text { NP test } \\
\text { MPT }\end{array}$ & SP test \\
\hline LnG/C & $-4,13^{*}$ & $-4,04^{*}$ & $-4,18^{*}$ & $0,54^{*}$ & $1,31^{*}$ & $-19,73^{*}$ & $-3,12^{*}$ & $0,16^{*}$ & 1,31 & $-4,66^{*}$ \\
\hline Ln I/G & $-5,66^{*}$ & $-5,66^{*}$ & $-5,66^{*}$ & 0,06 & $0,98^{*}$ & $-25,83^{*}$ & $-3,58^{*}$ & $0,13^{*}$ & 0,99 & $-5,46^{*}$ \\
\hline Ln Y & $-3,03^{*}$ & $-1,88^{* *}$ & $-4,14^{*}$ & $0,45^{* *}$ & $4,93^{*}$ & $-6,72^{*}$ & $-1,82^{*}$ & 0,27 & 3,66 & $-3,9^{* *}$ \\
\hline Ln C/P & $-6,09^{*}$ & $-5,99^{*}$ & $-6,13^{*}$ & $1,07^{*}$ & $0,97^{*}$ & $-26,4^{*}$ & $-3,62^{*}$ & 0,13 & 0,97 & $-7,02^{*}$ \\
\hline Ln N & $-1,49$ & $-1,57$ & $-2,73^{* *}$ & 0,13 & $4,81^{*}$ & $-6,12^{*}$ & $-1,49^{*}$ & $0,24^{*}$ & 4,78 & $-3,76^{* *}$ \\
\hline Ln W/P & $-4,18$ & $-3,16$ & $-4,38$ & 0,74 & 2,50 & $-14,20$ & $-2,66$ & 0,18 & 1,72 & $-3,40^{* *}$ \\
\hline
\end{tabular}

Source: Author's elaboration

There are strong discrepancies among the tests for the first differences in the series. While the first three tests confirm the stationarity of the series in the first four cases, for the Ln $\mathrm{N}$ series it is observed that the first difference has a unit root according to the first two tests yet it is stationary according to the rest of the tests.

However, in line with Perron (1989), the standard unit root tests tend to erroneously identify trending stationary processes as stationary in differences and may have very low power, even asymptotically, if changes in regime are ignored. Moreover, during the period studied, there was a great deal of social and political upheaval in Spain, which may have altered the course of public spending and the GDP. Therefore, supposing that the series might have breakpoints, different tests were conducted in order to detect them. Firstly, utilizing the sequential test of Bai-Perron, we obtained up to 3 structural breaks corresponding to the years 1978 (first democratic elections), 1990 (boom and crisis in building sector), and 2005 (beginning of financial and eco- 
nomic crisis). As for the Chow breakpoint test, and using the same breakpoints, it rejects the null hypothesis of non-existence of breakpoints at the points specified.

Given the existence of these breakpoints we conduct unit root tests allowing one or several structural breakpoints at unknown moments in time. The following chart displays the results obtained.

Table 3. Unit root tests considering structural breaks in the data ${ }^{22}$

\begin{tabular}{|c|c|c|c|}
\hline Variable & ZA test & P test & LP test \\
\hline LnG/C & $-3,03$ & $-3,11$ & $-3,84$ \\
\hline Ln I/G & $-4,60$ & $-4,59$ & $-4,85$ \\
\hline Ln Y & $-2,84^{*}$ & $-3,03$ & $-3,66$ \\
\hline Ln C/P & $-3,72$ & $-3,55^{*}$ & $-5,29$ \\
\hline Ln N & $-4,00$ & $-3,96$ & $-4,73$ \\
\hline Ln W/P & $-3,98^{*}$ & $-4,12^{*}$ & $-4,64$ \\
\hline
\end{tabular}

Source: Author's elaboration

The tests conducted are Zivot Andrews (1992) unit root test (ZV), Perron (1989) unit root test (P) and Lumsdaine-Papell (1997) Unit root test (LP). All the cases of breakpoints are detected endogeneously by the tests. In the first two cases a maximum of one breakpoint is admitted, while the LP test can detect two or more breakpoints. The ZV test detects breakpoints endogeneously in 1977, 1977, 2005, 2005, 1975 and 1972 for the different variables. In none of the cases does it reject the unit root hypothesis in the variables against the stationary alternative with structural change in both intercept and trend at an unknown date. The P test observes breakpoints in 1976, 1985, 1976, 1996, 1983 for the different variables. The lag selection method belongs to the criteria of Schwartz. It is assumed there is a constant and trend in the data generation process, and that there are breaks in the constant and trend. The critical values are taken from Perron and Vogelsang (1993). The values obtained with alternative specifications confirm the existence of unit roots in all of the variables in every case. The LP test detects breakpoints in 1980 and 1991, 1986 and 1999, 1981 and 2007, 1985 and 2002, 1988 and 1997, and 1971 and 1994 for the different series. In all the cases the statistical test values reveal, in relation to the critical values, that the series have a unit root against the most general alternative hypothesis.

$225 \% \mathrm{VC} Z \mathrm{ZA}=-5,08 ; \mathrm{P}=-5,59 ; \mathrm{LLS}=-3,06 ; \mathrm{LP}=-6,75$ 
Table 4. Unit root tests for the first differences considering structural breaks in the data

\begin{tabular}{|c|c|c|c|}
\hline Variable & ZA test & P test & LP test \\
\hline LnG/C & $-5,39$ & $-5,40$ & $-7,57$ \\
\hline Ln I/G & $-6,64$ & $-6,63$ & $-6,81$ \\
\hline Ln Y & $-5,20$ & $-7,91$ & $-7,33$ \\
\hline Ln C/P & $-5,20$ & $-7,91$ & $-7,33$ \\
\hline Ln N & $-7,91$ & $-5,20$ & $-9,20$ \\
\hline Ln W/P & $-7,18$ & $-7,92$ & $-6,88$ \\
\hline
\end{tabular}

Source: Author's elaboration

We can observe in all the tests that the variables are stationary in first differences.

Both of these preliminary steps are important for ensuring that we employ the correct econometric procedure. The estimation of a cointegrating relationship using Ordinary Least Squares, in general, is biased due to problems of endogeneity with the variables. Consequently, the corresponding t statistics do not follow a normal Student-t distribution, which is why it is not possible to make any kind of inference about its significance. On the other hand, performing a regression on the first difference of the variables when there actually exists a long-term relation of balance between them leads to the well-known problem of identifying omitted variables. In fact, what disappears in this type of regression is the error correction term.

Taking into consideration the existence of unit roots in all the model variables, it can be considered that cointegrating relationships do exist among them.

This analysis begins without taking into account the possible structural breaks that may be present among the different variables. In the first model the variables considered were LnG/C, LnI/G, LnY, LnC/P and LnN.

In order to consider the range of cointegration we based our work on the trace statistic and the asymptotic distribution of statistics, and the graph representations in cases where we encountered borderline situations. In these cases, we had to consider the behavior of the estimated cointegrating relationships presented in graphic format prior to selecting $r$. Another diagnostic tool is the use of graphs combined with the number of unit roots of the "matrix companion", which provides information on the pk roots that describe the dynamic properties of the process. This allowed us to see how close the largest unrestricted roots were to the unit circle.

The Johansen-Juselius cointegration test provides us with the following results. 
Table 5. Cointegration test without considering breakpoints

\begin{tabular}{|c|c|c|c|c|}
\hline & Eigenvalues & Trace Statistic & Critical Value & $p$-value \\
\hline$r=0$ & 0,55 & 80,13 & 69,61 & 0,000 \\
\hline$r=1$ & 0,43 & 43,36 & 47,71 & 0,124 \\
\hline$r=2$ & 0,32 & 14,24 & 29,80 & 0.827 \\
\hline
\end{tabular}

Source: Author's elaboration

The $r=0$ hypothesis is rejected, which means it has a cointegration vector considering an unrestricted constant in the data.

In order to analyze said cointegrating relationship in depth, we conduct various tests. Firstly, we consider the residuals graph.

Graph 3. Residuals graph

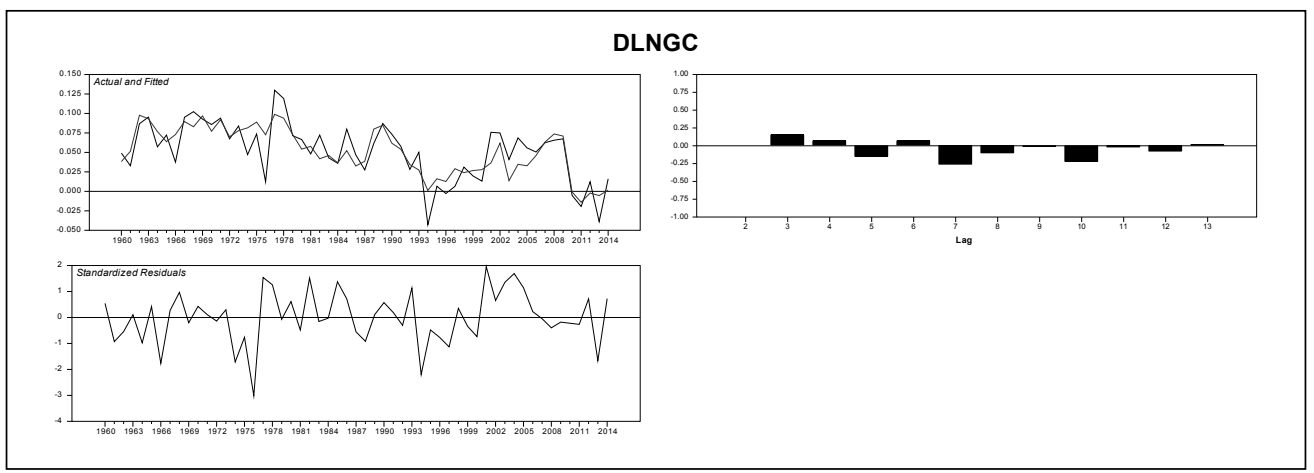

Source: Author's elaboration

The graphic has four parts: real and adjusted residuals of DLNGC, standardized residuals and histogram of the residuals, the histogram of the density function of the standardized residuals and the density of the normal distribution, as well as the Kolmogorov-Smirnov normality tests ${ }^{23}$ and the Jarque-Bera test. In the graph, large positive residuals can be observed in 1978, 1990 and 2005, precisely as predicted earlier with the Breush-Pagan test. The analysis of the residuals reveals problems with the normality, likely caused by the structural breaks, while the multivariant LM tests for conditional heterocedasticity are rejected. Finally, the normality test clearly rejects the null hypothesis (existence of normality ${ }^{24}$ ).

\footnotetext{
23 View Lilliefors (1967)

24 LJung-Box Statistic $\chi^{2}(275)=477,16(0.00)$ Multivariant test for autocorrelation $\chi^{2}(25)=29,12(0.259)$ $\chi^{2}(25)=22.95(0.580)$. Doornik-Hansen normality test $\chi^{2}(10)=43,16(0.00)$ LM tests for ARCH $\chi^{2}(225)=241,09(0.22) \chi^{2}(450)=491,33(0.087)$.
} 
Secondly, we used the companion matrix where the estimated eigenvalues are the reciprocal values of the roots of the characteristic polynomial $A(z)$; hence, the eigenvalues should be inside the unit disc or equal to 1 under the assumptions of the cointegrated VAR model.

If the process is $I(1)$, the number of roots in the companion matrix is equal to $\mathrm{p}-\mathrm{r}$, which is also the number of stochastic tendencies common to the model, which means the roots of A constitute a diagnostic tool to determine the range of $\Pi$ (cointegration matrix). In this case we consider two possibilities: $\mathrm{H}_{1}(5)$ and $\mathrm{H}_{1}$ (2). The former, by construction, possesses all the roots inside the unit circle but, in this case, four of them are very close to 1 . As for the latter, three unit roots are significant but it can be observed that the fourth is very close to 1 as well.

\section{Graph 4. Roots of the companion matrix}

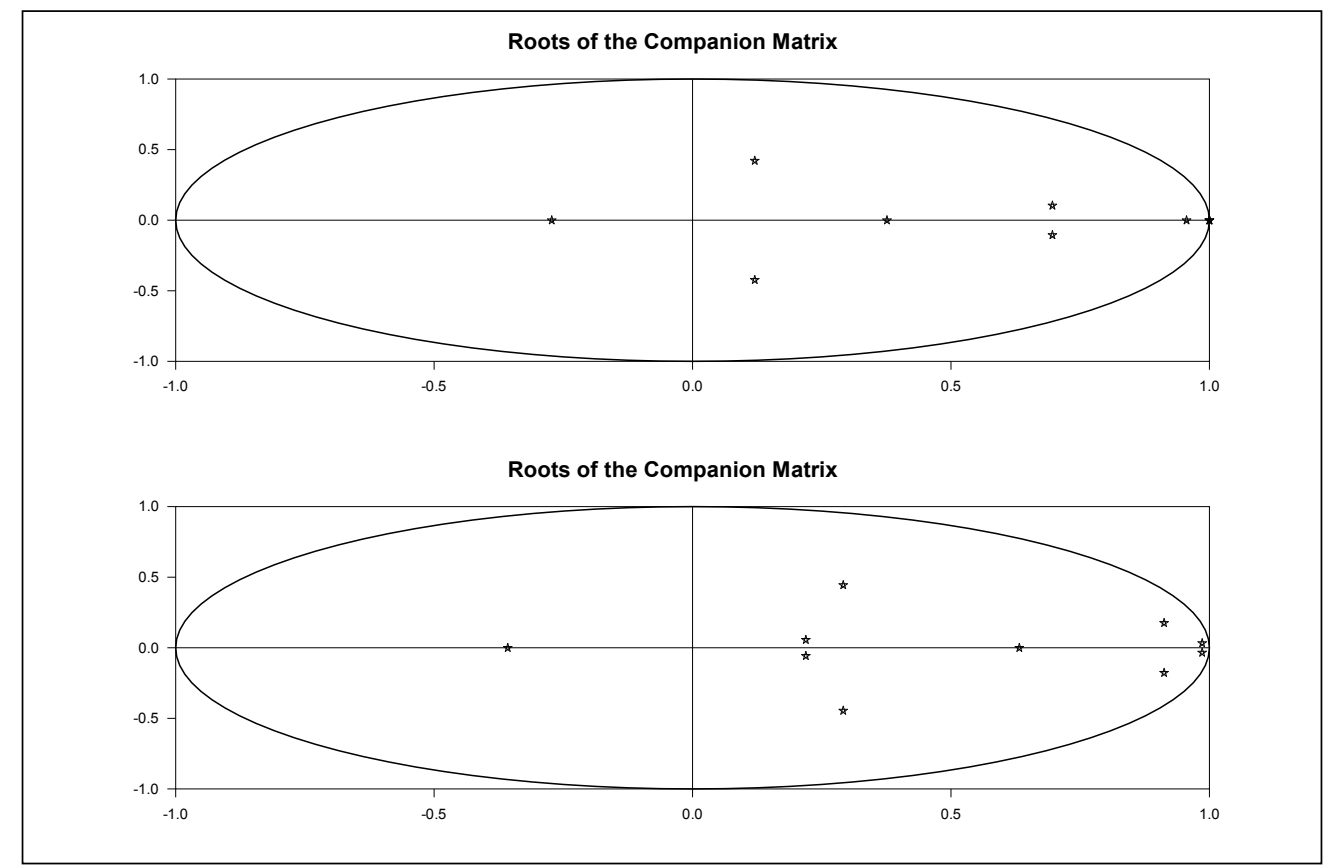

Source: Author's elaboration

More specifically, in the $\mathrm{H}_{1}$ (2) case the following roots are obtained: 1, 1, 1, 0,956, 0,696; and in the $H_{1}(5): 0,986,0,986,0,986,0,912,0,632$. In the first model (we assume $\mathrm{r}=2$ ) we discover three roots equal to 1 but there is a fourth that is very close to 1 . In the non-restricted second $(r=5)$, all the roots are inside the unit circle with four roots very close to 1 . In both cases there are four common tendencies, a fact that allows us to state that there is only one cointegrating relationship. 
Once the coefficient of the dependent variable is normalized to 1 , the cointegration vector is $[1,-6,87(-6,40), 2,7(4,40),-5,30(-6,45),-2,12(-6,77)]$. We obtained very different values from those that we had expected. If we represent the cointegrating relationship in graph form, we observe that around 1978, 1990 and 2005 there are outliers or breakpoints in the model, precisely as predicted by the Bai-Perron test. These structural breaks must be included in the cointegrating relationship in order to ensure results that agree with the economic reality.

\section{Graph 5. Cointegrating relationship}

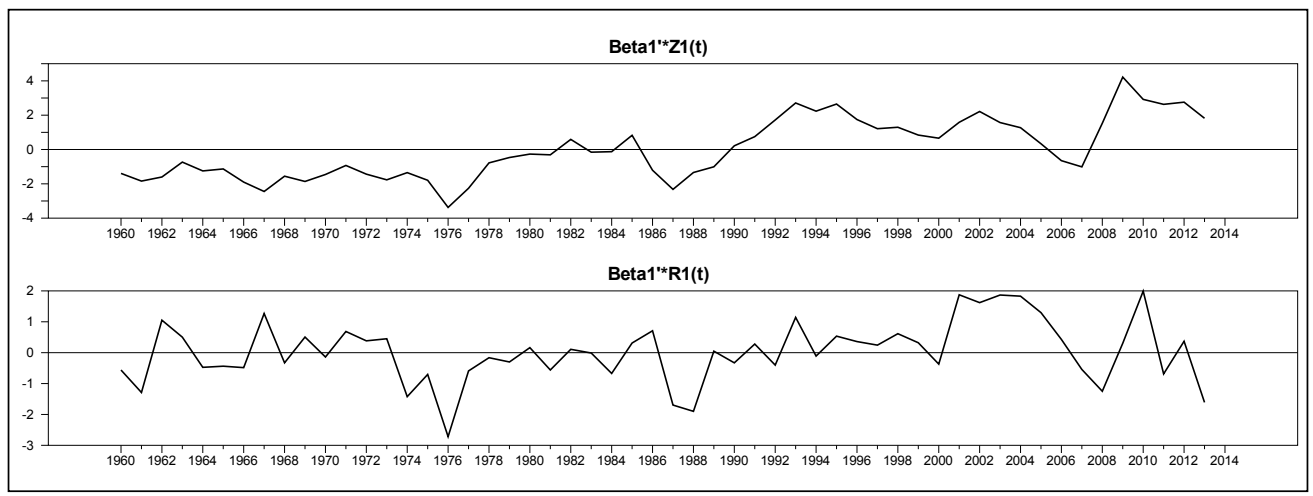

Source: Author's elaboration

Consequently, we conducted new cointegration tests which included these breakpoints. Given the methodological restrictions of Johansen et al. (2000), we included one or two breakpoints in order to later be able to test whether these breakpoints were the appropriate ones or not.

The following table displays the results obtained when considering the breakpoints of 1978, 1999 and 2005, both separately and together.

Table 6. Cointegration test considering breakpoints

\begin{tabular}{|c|c|c|c|c|}
\hline & Eigenvalues & Trace Statistic & Critical Value & $p$-value \\
\hline \multicolumn{5}{|c|}{1978} \\
\hline$r=0$ & 0,66 & 114,60 & 113,12 & 0,040 \\
\hline$r=1$ & 0,43 & 64,75 & 83,90 & 0,541 \\
\hline$r=2$ & 0,40 & 40,88 & 58,60 & 0,621 \\
\hline \multicolumn{5}{|c|}{1990} \\
\hline$r=0$ & 0,57 & 122,48 & 68,19 & 0,000 \\
\hline$r=1$ & 0,47 & 76,34 & 64,84 & 0,004 \\
\hline$r=2$ & 0,33 & 41,19 & 43,84 & 0,089 \\
\hline
\end{tabular}


Public expenditure and deficit in Spain (1958-2014)

\begin{tabular}{|c|c|c|c|c|}
\hline & Eigenvalues & Trace Statistic & Critical Value & p-value \\
\hline \multicolumn{5}{|c|}{2005} \\
\hline$r=0$ & 0,60 & 123,31 & 106,05 & 0,001 \\
\hline$r=1$ & 0,46 & 73,09 & 73,32 & 0,076 \\
\hline$r=2$ & 0,33 & 38,74 & 49,84 & 0,354 \\
\hline \multicolumn{5}{|c|}{1978 and 1990} \\
\hline$r=0$ & 0,63 & 133,98 & 102,51 & 0,000 \\
\hline$r=1$ & 0,46 & 78,78 & 75,14 & 0,026 \\
\hline$r=2$ & 0,35 & 45,12 & 51,77 & 0,170 \\
\hline \multicolumn{5}{|c|}{1978 and 2005} \\
\hline$r=0$ & 0,64 & 134,62 & 102,80 & 0,000 \\
\hline$r=1$ & 0,46 & 79,01 & 75,41 & 0,026 \\
\hline$r=2$ & 0,37 & 46,16 & 52,03 & 0,177 \\
\hline \multicolumn{5}{|c|}{1990 and 2005} \\
\hline$r=0$ & 0,62 & 134,80 & 119,52 & 0,004 \\
\hline$r=1$ & 0,51 & 81,81 & 85,39 & 0,087 \\
\hline$r=2$ & 0,33 & 43,07 & 57,01 & 0,415 \\
\hline
\end{tabular}

Source: Author's elaboration

The results in the previous table reveal a cointegrating relationship when considering the breakpoint in 1978 and 2005. It also indicates the existence of two cointegration vectors considering the breakpoint in 1990, two cointegration vectors considering 1978 and 1990 and also 1978 and 2005, and one lone cointegration vector considering breakpoints in 1990 and 2005.

Along with the cointegration tests we consider the roots of the companion matrix in each case, as well as the graphs of the cointegrating relationships. The following is a summarized version of the root values of said matrices.

Table 7. Root of the companion matrix for $\mathrm{H}(2)^{25}$

\begin{tabular}{|c|c|c|c|c|c|c|}
\hline & 1978 & 1990 & 2005 & $\begin{array}{c}1978 \text { and } \\
1990\end{array}$ & $\begin{array}{c}1978 \text { and } \\
2005\end{array}$ & $\begin{array}{c}1990 \text { and } \\
2005\end{array}$ \\
\hline Root 1 & 1 & 1 & 1 & 1 & 1 & 1 \\
\hline Root 2 & 1 & 1 & 1 & 1 & 1 & 1 \\
\hline Root 3 & 1 & 1 & 1 & 1 & 1 & 1 \\
\hline
\end{tabular}

25 For $\mathrm{H}(5)$ similar values are obtained 


\begin{tabular}{|c|c|c|c|c|c|c|}
\hline & 1978 & 1990 & 2005 & $\begin{array}{c}1978 \text { and } \\
1990\end{array}$ & $\begin{array}{c}1978 \text { and } \\
2005\end{array}$ & $\begin{array}{c}1990 \text { and } \\
2005\end{array}$ \\
\hline Root 4 & 0,986 & 0,972 & 0,943 & 0,963 & 0,919 & 0,978 \\
\hline Root 5 & 0,872 & 0,663 & 0,715 & 0,647 & 0,643 & 0,621 \\
\hline
\end{tabular}

Source: Author's elaboration

Given the values of the above matrix and the graphs of the cointegrating relationships, we can conclude, out of all the cases, there is only one cointegrating relationship ${ }^{26}$, which is summarized in the following table.

Table 8. Cointegration equation in break points ${ }^{27}$

\begin{tabular}{|c|c|c|c|c|c|c|c|c|}
\hline & $\mathrm{Ln} \mathrm{G} / \mathrm{C}$ & $\mathrm{L} n \mathrm{I} / \mathrm{G}$ & LnY & $\mathrm{L} n \mathrm{C} / \mathrm{P}$ & $\mathrm{L} n \mathrm{~N}$ & Break 1 & Break 2 & Cte \\
\hline 1978 & 1 & $\begin{array}{l}-2,24 \\
(-4,65)\end{array}$ & $\begin{array}{l}1,60 \\
(2,90)\end{array}$ & $\begin{array}{c}1,10 \\
(1,46)\end{array}$ & $\begin{array}{c}0,96 \\
(5,20)\end{array}$ & $\begin{array}{c}0,06 \\
(1,89)\end{array}$ & & $\begin{array}{l}16,10 \\
(8,67)\end{array}$ \\
\hline 1990 & 1 & $\begin{array}{l}-5,38 \\
(-6,11)\end{array}$ & $\begin{array}{l}2,35 \\
(3,12)\end{array}$ & $\begin{array}{c}4,64 \\
(5,16)\end{array}$ & $\begin{array}{c}1,85 \\
(5,79)\end{array}$ & $\begin{array}{c}0,90 \\
(1,06)\end{array}$ & & $\begin{array}{l}32,78 \\
(7,33)\end{array}$ \\
\hline 2005 & 1 & $\begin{array}{l}-5,28 \\
(-7,07)\end{array}$ & $\begin{array}{c}2,23 \\
(4,88)\end{array}$ & $\begin{array}{c}3,24 \\
(5,32)\end{array}$ & $\begin{array}{c}2,05 \\
(7,70)\end{array}$ & $\begin{array}{c}0,61 \\
(2,65)\end{array}$ & & $\begin{array}{l}41,36 \\
(7,77)\end{array}$ \\
\hline $\begin{array}{c}1978 \text { and } \\
2005\end{array}$ & 1 & $\begin{array}{l}-2,70 \\
(-6,87)\end{array}$ & $\begin{array}{c}0,37 \\
(1,54)\end{array}$ & $\begin{array}{c}1,47 \\
(4,68)\end{array}$ & $\begin{array}{c}0,94 \\
(6,31)\end{array}$ & $\begin{array}{c}0,26 \\
(3,78)\end{array}$ & $\begin{array}{c}0,18 \\
(1,41)\end{array}$ & $\begin{array}{l}20,90 \\
(6,67)\end{array}$ \\
\hline $\begin{array}{c}1978 \text { and } \\
1990\end{array}$ & 1 & $\begin{array}{l}-2,34 \\
(-6,47)\end{array}$ & $\begin{array}{l}0,29 \\
(0,91)\end{array}$ & $\begin{array}{c}1,67 \\
(4,10)\end{array}$ & $\begin{array}{c}0,81 \\
(5,69)\end{array}$ & $\begin{array}{c}0,28 \\
(4,64)\end{array}$ & $\begin{array}{c}0,08 \\
(1,12)\end{array}$ & $\begin{array}{l}16,92 \\
(8,46)\end{array}$ \\
\hline $\begin{array}{c}1990 \text { and } \\
2005^{28}\end{array}$ & 1 & $\begin{array}{l}-4,10 \\
(-7,89)\end{array}$ & $\begin{array}{c}2,38 \\
(5,33)\end{array}$ & $\begin{array}{c}3,27 \\
(5,86)\end{array}$ & $\begin{array}{c}1,97 \\
(9,44)\end{array}$ & $\begin{array}{c}0,32 \\
(3,05)\end{array}$ & $\begin{array}{c}0,51 \\
(3,41)\end{array}$ & $\begin{array}{l}37,10 \\
(10,3)\end{array}$ \\
\hline
\end{tabular}

Source: Author's elaboration

Upon analyzing the above results, we can consider a priori the 1978 and 2005 breakpoints to be significant. The first corresponds to the beginning of the democratic era in Spain, while the second marks the start of the current economic crisis.

In view of these considerations, we conduct a reestimation of the cointegration vector taking 1978 and 2005 as breakpoints, along with 1978 and 1990 and, 1990 and 2005. The equations obtained are displayed in the previous table.

\footnotetext{
26 In all cases the coefficient LnG/C was normalized to 1

27 In parentheses, $t$ statistics

28 In this model the equality to zero of the breakpoint coefficients does not reject the null in the case of 1990 with $\chi(1)=2,73$ and a $p$-value of 0.098 , but it does reject it for 2005 with $\chi=6,89$ and a p-value of 0.009 . Consequently, we consider that the model that best adjusts to reality is that which considers one lone breakpoint in 1978 .
} 
We conducted various tests to analyze the suitability of the model. Firstly, different restrictions were applied to the subsets of the $\beta$ vectors. We were initially interested in the validation of the structural breaks. To this end, we carried out X2 tests of equality to zero on the coefficients of said breaks. In the case of structural breaks in 1978 and 2005, we found that in the case of the former, the value was $\chi^{2}(1)=6,20$, with a p-value of 0,013 , which clearly rejects the equality to zero of the corresponding coefficient. As for 2005, the value obtained was X2(1) $=1,41$, with a p-value of 0,224, which leads us to accept the null hypothesis.

With regard to the structural breaks in 1978 and 1990, the same test provided values of $\chi^{2}(1)=0,52$, with a $p$-value of 0,470 , which means we cannot reject the null hypothesis of equality to zero for the coefficient corresponding to 1990. In the case of the breakpoint in 1978 , the value was $\chi^{2}(1)=9,71$, with a p-value 0,002 , which allows us to reject the null hypothesis of equality to zero for the coefficient corresponding to the breakpoint in 1978.

In light of these results, the cointegration vector that should be applied is that corresponding to the 1978 breakpoint, which is displayed in the table above.

Regarding this cointegrating relationship, various hypothesis tests were carried out on its $\beta$ coefficients. In the tests of equality to zero of the variable coefficients of the cointegrating relationship, we reject the null hypothesis in all cases ${ }^{29}$. This was not the case in equality to 1 of the LNY coefficient, where we obtained a value of $\chi^{2}(2)=4,01$, with a p-value of 0,134 . Similarly, we accept the null hypothesis in the case of equality to 1 of the population coefficient with a value of $\chi^{2}(2)=3,72$, with a $\mathrm{p}$-value of 0.155 .

Finally, we have conducted weak exogeneity tests on the model variables, rejecting the null hypothesis of exogeneity in all cases.

The results indicate that the deficit has a marked influence on spending growth with an elasticity of 2,24. The LnY coefficient reveals a validation of Wagner's Law during this period ${ }^{30}$. The coefficient of the price differential would indicate a positive influence on public spending, as well as on the population coefficient, albeit the magnitude of the latter suggests economies of scale in public spending.

Based on the previous cointegrating equation, the corresponding error correction model was formulated and is presented as follows:

29 The values of chi-squared are 8,5, 7,31, 6,95 and 12,29 for the respective variables.

30 In Jaén and Molina $(1997,1999)$ it is seen how the data rejected said hypothesis, although works like that of Legrenzi and Milas (2002) attribute the no validation in Italy to a lack of other variables, similar to what occurred in this case. 


$$
\begin{aligned}
& \Delta \mathrm{Ln}\left(\frac{\mathrm{G}}{\mathrm{C}}\right)=-0,25(-2,05) \Delta \mathrm{Ln}\left(\frac{\mathrm{G}}{\mathrm{C}}\right)_{-1}-0,30(-3,4) \Delta \mathrm{Ln}\left(\frac{\mathrm{I}}{\mathrm{G}}\right)_{-1}+ \\
& 0,42(4,4) \Delta \mathrm{LnY}_{-1}-0,13(-1,08) \Delta \mathrm{Ln}\left(\frac{\mathrm{C}}{\mathrm{P}}\right)_{-1}-0,03(0,48) \Delta \mathrm{LnN}_{-1}+\quad[10]^{31} \\
& 0,05(4,9) \mathrm{Dl} 978_{-1}-3,4(-7,2)-0,12 \mathrm{ECT}_{-1}
\end{aligned}
$$

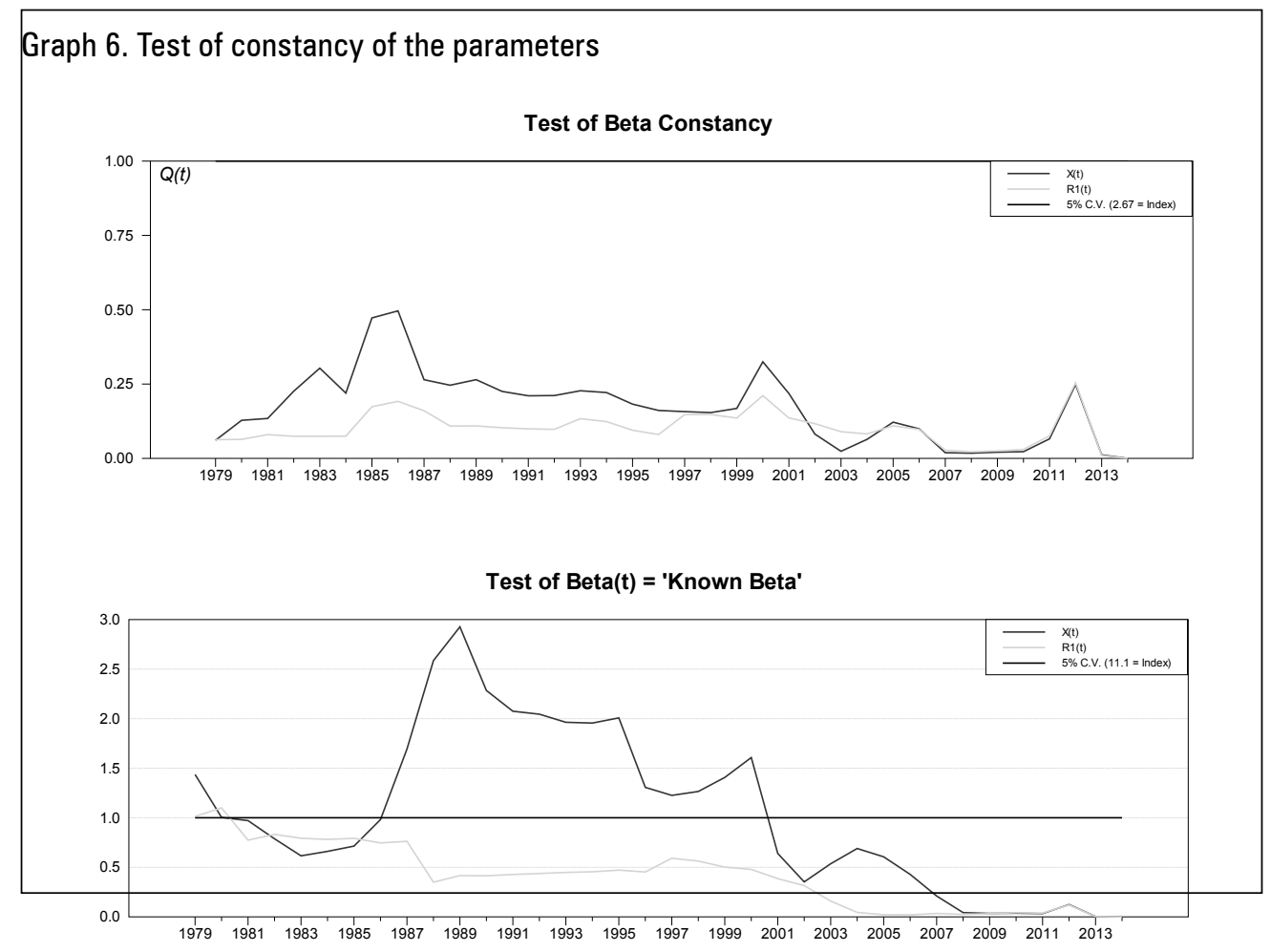

Source: Author's elaboration

The error correction model reveals the lack of short-term influence on the indicative variables of price differential and population.

In order to analyze the constancy of the parameters we utilized recursive estimation methods. The corresponding calculations were carried out in two different ways. Using a basic sampling, we either re-estimated all the parameters in each period (X-form), or we merely re-estimated the long-term estimators of $\alpha$ and $\beta$, excluding

31 In parentheses, $t$ statistics 
the short-term dynamic utilizing the parameter estimators in the complete sampling (Rl-form).

The first contrast, which was for the constancy of $\beta$, revealed the maximum difference between the value of $\beta$ in the base sampling and the value of $\beta$ as the sampling size increases. The result indicated that all the values taken throughout the period were in the range below the critical value. The second recursively tests whether any fixed value of $\beta$, the estimator of $\beta$ in the complete sampling, was contained within the expanded space by the estimator of $\beta$ in the base sampling. Although in method $X$ the behavior was not very suitable (considering that until 2001 the hypothesis was not validated), this was not the case in the second method, in which the hypothesis was validated from 1981 .

\section{Graph 7. Test of constancy of the parameters}

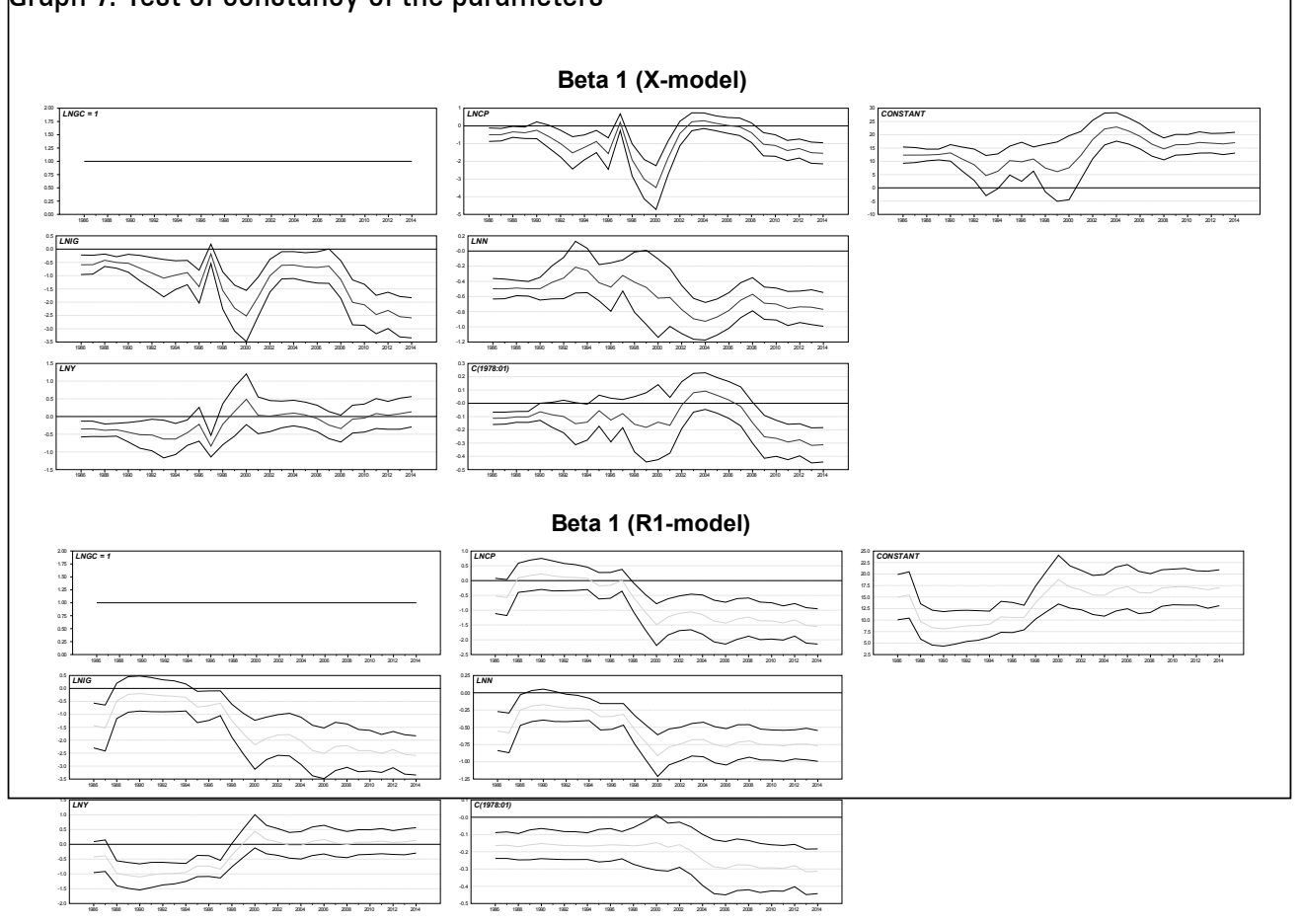

Source: Author's elaboration

The above graphs show the recursive estimation of the cointegrating equation coefficients using the period 1960-1985 as the base simple. Both graphs reveal that apart from small fluctuations, the estimators of the coefficients of all the model variables are constant. The breakpoint appears again in the form of a peak in the 
various graphs, followed by a rather steady trajectory thereafter.

We conducted another parallel study, albeit less detailed, utilizing the LnW variable rather than LnN. Initially, we considered that there were no structural breaks in the data. In those conditions the Johansen-Juselius cointegration test provided the following results:

Table 9. Cointegration test without considering breakpoints

\begin{tabular}{|c|c|c|c|c|}
\hline & Eigenvalues & Trace Statistic & Critical Value & $p$-value \\
\hline $\mathrm{r}=0$ & 0,52 & 195,38 & 85,55 & 0,001 \\
\hline $\mathrm{r}=1$ & 0,38 & 64,68 & 63,66 & 0,041 \\
\hline $\mathrm{r}=2$ & 0,30 & 38,39 & 42,77 & 0,132 \\
\hline
\end{tabular}

Source: Author's elaboration

Graph 8. Residuals graph

DLNGC
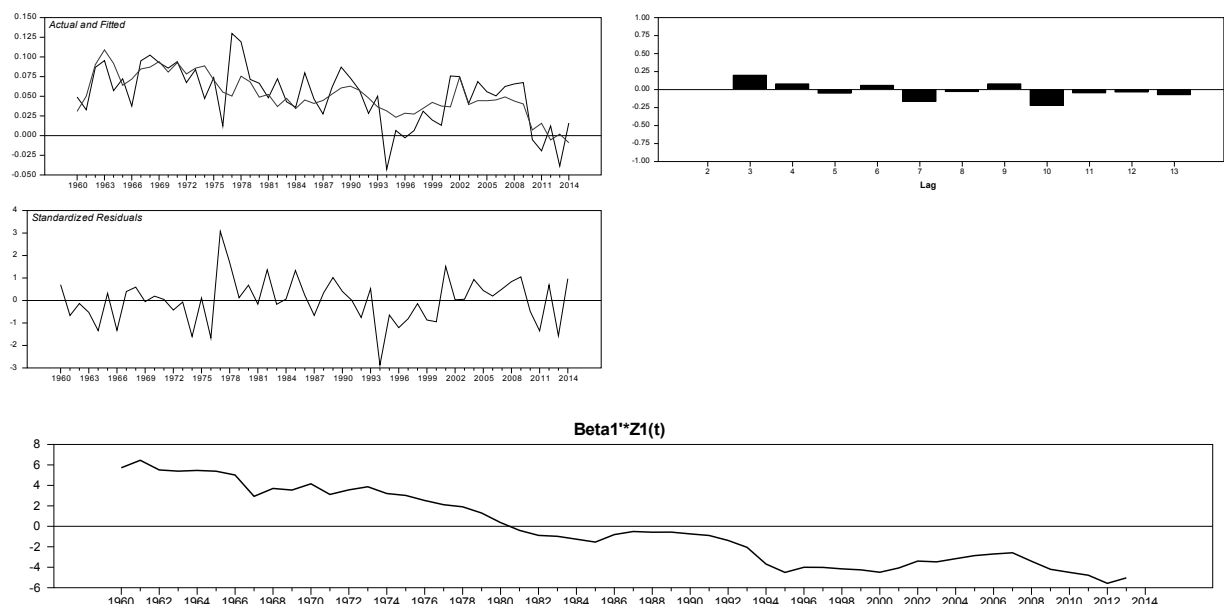

Beta1"*R1(t)

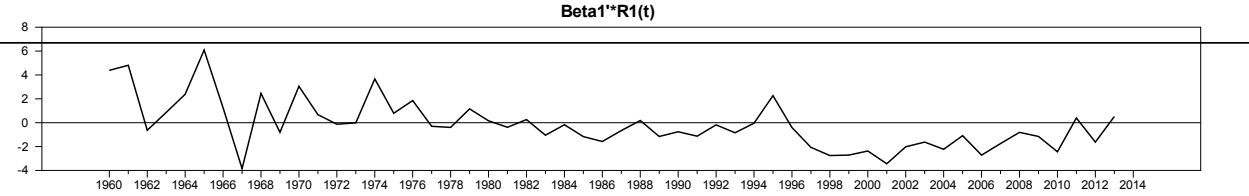

Source: Author's elaboration

The hypothesis $r=0$ is rejected, which means there is a cointegration vector when considering an unrestricted constant in the data. We have our doubts with regard to the second unit root as both the statistic and the $\mathrm{p}$-value reveal a value close to 0.05 . In this case we used the same test methods as in the previous case: residuals, companion matrix and cointegration vector. 
In the case of the companion matrix and $\mathrm{H}(2)$ we obtained values of $1,1,1,0,939$ and 0,686 , which provided us with four unit roots and one cointegration vector. The cointegration vector was $[1,4,9(0,64),-17,29(-2,01), 4,98(0,74), 4,5(0,76)]-$ a result which is hardly in accordance with the economic reality. Taking into consideration the results obtained for the residuals and cointegration equation, we conducted the same analysis for cointegrating relationships considering the different structural breakpoints. The results are displayed in the following table.

Table 10. Cointegration test considering breakpoints

\begin{tabular}{|c|c|c|c|c|}
\hline & Eigenvalues & Trace Statistic & Critical Value & $p$-value \\
\hline \multicolumn{5}{|c|}{1978} \\
\hline$r=0$ & 0,62 & 134,17 & 113,12 & 0,010 \\
\hline$r=1$ & 0,48 & 81,16 & 83,90 & 0,079 \\
\hline$r=2$ & 0,32 & 44,86 & 58,60 & 0,432 \\
\hline \multicolumn{5}{|c|}{1990} \\
\hline$r=0$ & 0,44 & 115,35 & 113,05 & 0,035 \\
\hline$r=1$ & 0,42 & 83,48 & 83,92 & 0,054 \\
\hline \multirow[t]{2}{*}{$r=2$} & 0,37 & 53,80 & 58,61 & 0,123 \\
\hline & & 2005 & & \\
\hline$r=0$ & 0,52 & 125,32 & 114,04 & 0,007 \\
\hline$r=1$ & 0,48 & 85,34 & 82,12 & 0,028 \\
\hline$r=2$ & 0,34 & 49,78 & 54,99 & 0,129 \\
\hline \multicolumn{5}{|c|}{1978 and 1990} \\
\hline$r=0$ & 0,63 & 148,72 & 102,51 & 0,000 \\
\hline$r=1$ & 0,51 & 94,21 & 75,14 & 0,001 \\
\hline$r=2$ & 0,38 & 55,28 & 51,77 & 0,023 \\
\hline$r=3$ & 0,24 & 28,81 & 32,12 & 0,114 \\
\hline \multicolumn{5}{|c|}{1978 and 2005} \\
\hline$r=0$ & 0,62 & 141,43 & 102,80 & 0,000 \\
\hline$r=1$ & 0,50 & 88,50 & 75,41 & 0.004 \\
\hline$r=2$ & 0,35 & 50,44 & 52,03 & 0.069 \\
\hline \multicolumn{5}{|c|}{1990 and 2005} \\
\hline$r=0$ & 0,55 & 128,84 & 119,52 & 0.012 \\
\hline
\end{tabular}




\begin{tabular}{|c|c|c|c|c|}
\hline & Eigenvalues & Trace Statistic & Critical Value & $p$-value \\
\hline $\mathrm{r}=1$ & 0,45 & 84,92 & 85,39 & 0.054 \\
\hline $\mathrm{r}=2$ & 0,322 & 51,77 & 57,01 & 0.127 \\
\hline
\end{tabular}

\section{Source: Author's elaboration}

The results in this table indicate a cointegrating relationship when considering the breakpoints in 1978 and 1990 and two cointegrating relationships in 2005.

When two breakpoints are considered, a cointegrating relationship is obtained for 1990 and 2005, two relationships for 1978 and 2005, and up to three relationships for 1978 and 1990.

In order to not overextend the analysis any further we verified that all the cointegrating relationships determined that the hypothesis of equality to zero of the coefficients corresponding to the breakpoints in 1990 and $2005^{32}$ could not be rejected. Finally, we obtained a cointegration equation corresponding to the breakpoint in 1978:

$$
\begin{aligned}
& \operatorname{Ln}\left(\frac{G}{C}\right)=-1,04(-4,08) \operatorname{LN}\left(\frac{I}{G}\right)+0,67 \operatorname{LnY}-1,64(-5,25) \\
& \operatorname{LnN}+1,34(6,14) \operatorname{Ln}\left(\frac{\mathrm{W}}{\mathrm{P}}\right)+0,44(7,61) \mathrm{D} 1978
\end{aligned}
$$

where the equality to zero of the coefficients was rejected in all cases. In the tests of equality to 1 , the null was accepted in the case of LnI/G with a value of $\chi^{2}(1)$ $=0,01$, with a p-value of 0,925 , as well as the equality to 1 of the coefficient LnC/P with $\chi^{2}(1)=0,002$, with a $p$-value of 0,925 . However, the equality to 1 was rejected for the coefficient LnY with $\chi^{2}(1)=9,33$ and a $p$-value of 0.002 .

The results reveal an elasticity of the deficit approximately equal to 1 , which means the B-W hypothesis is confirmed. Moreover, income has an elasticity of less than 1, meaning that Wagner's Law is accepted. Finally, the Baumol disparity hypothesis would then be confirmed since it predicts that the relative price coefficient is negative.

Based on the previous cointegration equation, the corresponding error correction model was formulated.

32 The corresponding calculations are available to whomever requests them. 


$$
\begin{aligned}
& \Delta \operatorname{Ln}\left(\frac{\mathrm{G}}{\mathrm{C}}\right)=0,03(0,22) \operatorname{Ln}\left(\frac{\mathrm{G}}{\mathrm{C}}\right)_{-1}-0,13(-1,4) \Delta \operatorname{Ln}\left(\frac{\mathrm{I}}{\mathrm{G}}\right)_{-1}+0,40(3,42) \Delta \operatorname{Ln}+0,04(0,33) \\
& \Delta \mathrm{LnN}_{-1}-0,09(-0,82) \Delta \mathrm{Ln}(-)+0,06(2,34) \mathrm{Dl} 978_{-1}-3,4(-7,2)-0,15 \mathrm{ECT}_{-1}
\end{aligned}
$$

In parallel to the first model, we also analyzed the constancy of the parameters in the cointegration vector. In this case we limited ourselves to conducting the recursive estimation of the cointegration equation coefficients ${ }^{33}$.

Graph 9. Test of constancy of the parameters

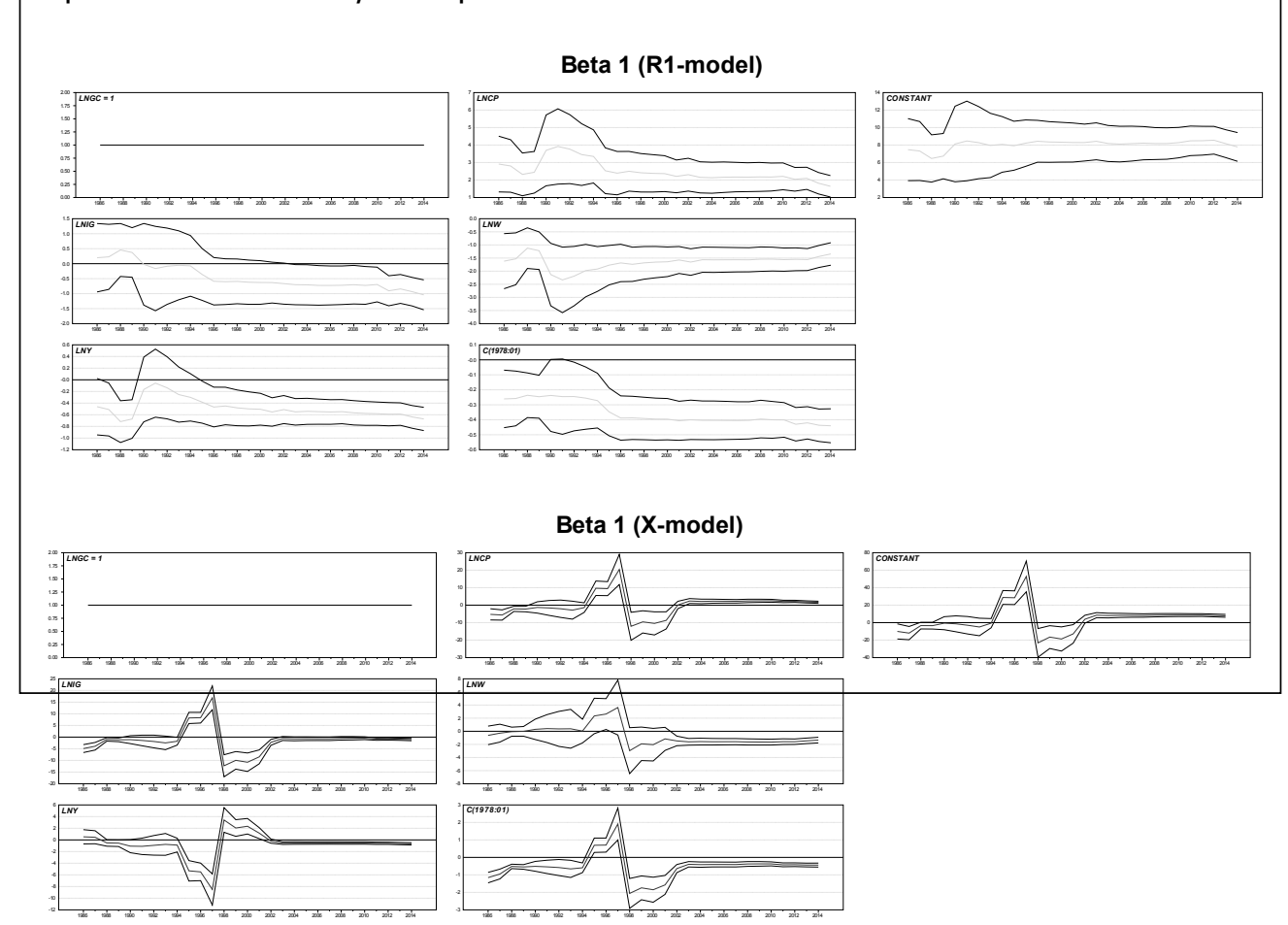

Source: Author's elaboration

Both graphs show that apart from small fluctuations the estimators of all the model variable coefficients are constant. Another breakpoint appears once again in the form of a peak in the various graphs, followed by a rather steady trajectory thereafter.

\section{SUMMARY AND CONCLUSIONS}

33 The rest of the calculations are available to whomever requests them. 
This study sought to conduct an analysis of public spending growth in Spain based on a reduced model test of the B-W hypothesis. This model also allowed us to analyze the possible validation of one of the versions of Wagner's Law, as well as the Baumol disparity hypothesis.

The present work makes two important contributions to the Spanish literature on this subject. Firstly, it encompasses a significantly longer sampling period than those considered in previous studies, which made it necessary to analyze the major changes that took place in Spain, from both economic and political perspectives. The most notable event was the end of Franco's dictatorship, which gave way to the founding of a democratic government that had to address social demands which, in turn, implied increased public spending. The other two important events that were spurred by economic phenomena were joining the EU and the recent economic crisis. By utilizing techniques like unit roots and cointegration with structural breaks, we came to the conclusion that the only event that significantly affected the trajectory of public spending was the founding of the democratic government. Bearing this in mind, the two alternative equations formulated over the course of the study were estimated.

The coefficients obtained in the first equation allowed us to confirm the validation of the B-W hypothesis, in broad terms. Firstly, precisely as expected, the public deficit coefficient was negative, which implies that a relative increase in tax revenues makes the demand for government spending decrease; or, in other terms, deficit increases government spending. This result is the same as that of Niskanen (1978) Raymond and Gonzalez-Paramo (1988) and Jaén (1999), and it agrees with Buchanan-Wagner's proposition. The coefficient estimated for the income elasticity was positive with a value very close to the unit, which indicates, in line with Wagner's Law, that a rise in income increases government spending. In the case of relative prices, the value obtained was positive, contradicting the Baumol production disparity hypothesis. Finally, the fact that the population coefficient value was less than 1 suggests economies of scale in public spending as population increases.

As regards the second equation, the results obtained were slightly different. The elasticity of public spending is approximately equal to 1, which confirms the B-W hypothesis. Moreover, the income had an elasticity less than 1, which means Wagner's Law is not accepted. Finally, the Baumol disparity hypothesis is validated considering it predicts that the relative prices coefficient is negative.

If we compare the results obtained with the two equations, they are rather different. On one hand, both cases confirm the B-W hypothesis, but the results for the rest of the variables are quite different. This indicates instability when the variables 
in the model are changed as merely one modification leads to rather varied results. However, on the other hand, we can observe stability in each model as the parameters obtained in both are constant throughout the various sampling sizes, exactly as shown in the recursive graphs.

\section{REFERENCES}

Asworth, J. (1995). The Empirical Relationship between Budgetary Deficits and Government Expenditure Growth: An Examination using Co-integration. In: Public Finance, Vol. 50, No. 1, pp. $1-18$.

Beck, M. (1976). The Expanding Public Sector: Some Contrary Evidence. In: National Tax Journal, Vol. 29, No. 1, pp. 15-2.

Beck, M. (1981). Government Spending. Trend and Issues. New York: Praeger, First edition, 135p.

Bergstrom, T.C. and Goodman, R.P. (1973). Private Demands for Public Goods. In: American Economic Review Vol. 63, No. 3, pp. 280-296.

Borcherding, T.E. (1985). The Causes of Government Expenditure Growth: A Survey of the U.S. Evidence. In: Journal of Public Economics Vol. 28, No. 3, pp. 359-382.

Borcherding, T.E. and Deacon, R.T. (1972). The Demand for Services of Non-Federal Governments. In: American Economic Review, Vol. 62, No. 5, p. 891-901.

Buchanan J. and Wagner, R. (1977): Democracy in Deficit: The Political Legacy of Lord Keynes. Academic Press. New York, 185p.

Courakis, A.S.; Roque-Moura, F. and Tridimas, G. (1993). Public Expenditure Growth. In Greece and Portugal: Wagner's Law and Beyond. In: Applied Economics, Vol. 25, No. 1, pp. 125-134.

Craigwell, R. (1991). Government deficits and spending in Barbados: An empirical test of the Buchanan-Wagner hypothesis. In: Public Finance, Vol. 46, No. 3, pp. 373-381.

Christopoulos, D. and Tsionas, E.G. (2003). Testing the Buchanan-Wagner hypothesis: European evidence from panel unit root and cointegration tests. In: Public Choice Vol. 115, No. 3 , pp. 439-453.

Elliot, G.; Rothenberg, T. and Stock, J. (1996). Efficient Tests for an Autoregressive unit root. In: Econometrica, Vol. 64, No. 4, pp. 813-836.

Fuentes, E. and Barea, J. (1996). El Déficit Público en la Democracia Española. In: Papeles de Economía Española No. 68, pp. 86-191.

Hernández Garcia, G. (1996). La deuda pública en la democracia. In: Papeles de Economía Española No. 68, pp. 214-227.

Hondroyiannis, G. and Papapetrou, E. (2001). An investigation of the public deficits and government spending relationship: evidence for Greece. In: Public Choice, Vol. 107, No. 1-2, pp. 169-182.

Jaén, M. (1999). Gasto público, déficit y cointegración. Un análisis de la hipótesis Buchanan-Wagner 
en el caso español. In: Hacienda Pública Española Vol. 150, No. 3, p.161-172.

Jaén, M. (2011). Empirical analysis of Wagner's law for the Spain's regions. In: International Journal of Academic Research in Accounting, Finance and Management Sciences. Vol. 1, No. 1, p. 1-17.

Jaén, M. and Molina, A. (1997). Un estudio empírico de la ley de Wagner aplicado al caso español. In: Hacienda Pública Española, No. 141 142, pp. 277-285.

Jaén, M. and Molína, A. (1999). Evidencia Empírica Adicional sobre la Ley de Wagner: España 1901-1992. In: Hacienda Pública Española, No. 148, pp. 169-174.

Johansen, S. (1991). Estimation and Hypothesis Testing of Cointegration Vectors in Gaussian Vector Autoagressive Models. In: Econometrica, Vol. 52, No. 6, pp. 1551-80.

Johansen, S. and Juselius, K. (1990). Maximun Likelihood Estimation and Inference on Cointegration- With Applications to the Demand for Money. In: Oxford Bulletin of Economics and Statistics, Vol. 52, No. 2, pp. 169-210.

Johansen, S. and Juselius, K. (1992). Testing Structural Hypotheses in a Multivariate Cointegration Analysis of the PPP and the UIP for UK. In: Journal of Econometrics, Vol. 53, No. 1 3, pp. 211-244.

Johansen, S.; Mosconi, R. and Nielsen, B (2000). Cointegration analysis in the presence of structural breaks in the deterministic trend. In: Econometric Journal, Vol. 3, No. 2, pp. 216-249.

Khan, A. H. (1988). Public Spending and deficits: Evidence from a developing economy. In: Public Finance, Vol. 43, No. 3, pp. 396-402.

Kuckuck, J. (2014). Testing Wagner's Law at different stages of economic development. In: Finanzarchiv/Public Finance Analysis, Vol. 70, No. 1, pp. 128-168.

Kwiatkowski, D.; Phillips, P.; Schmidt,P. and Shin,Y. (1992). Testing the Null Hypothesis of Stationary against the Alternative of a unit root. In: Journal of Econometrics, Vol. 54, No. 1-3, pp. 159-178.

Legrenzi, G.; Milas, C (2002). The Role of Omitted Variables in Identifying a Long-run Equilibrium Relationship for the Italian Government Growth. In: International Tax and Public Finance, Vol. 9, No. 4, pp. 435-449.

Lilliefors, H (1967). On the Kolmogorv-Smirnov test for normality with mean and variance unknown. In: Journal of the American Statistical Association Vol. 62 pp. 399-402.

Lumsdaine, R. and D. Papell (1997). Multiple trend breaks and the unit root hypothesis. In: Review of Economics and Statistics, Vol. 79, No. 2, pp. 212-218.

MacKinnon, J, G. (1991). Critical Values for Cointegration Tests, Chapter 13. In: R. F. Engle and C. W. J. Granger (eds.), Long-run Economic Relationships: Readings in Cointegration, Oxford: Oxford University Press, 19p.

Ng, S. and Perron, P. (2001). Lag Length Selection and the Construction of unit root Tests with Good Size and Power. In: Econometrica, Vol. 69 No. 6, pp. 1519-1554.

Niskanen, W. (1978). Deficits, Government Spending and Inflation. What is the Evidence? In: Journal of Monetary Economics, Vol. 4, No. 3, pp. 591-602.

Perron, P (1989). The Great Crash, the Oil Price Shock and the Unit Root Hypothesis. In: Econo- 
metrica, Vol. 57, No. 1, pp. 215-36.

Perron, P. and Vogelsand, T. J. (1993). The Great Crash, the Oil Price Shock and the Unit Root Hypothesis: Erratum. In: Econometrica. Vol. 61, No. 1, pp. 248-249

Priesmeier, C. and Koester, G. (2012). Does Wagner's law ruin the sustainability of German public finances? Discussion Paper, No. 8, Deutsche Bundesbank, 48p.

Provopoulos, G.A. (1982). Public spending and deficits: The Greek experience. In: Public Finance, Vol. 37, No. 3, pp. 422-446.

Raymond, J.L. and González-Páramo, J.M. (1988). Déficit, Impuestos y Crecimiento del Gasto Público. In: Papeles de Economía Española No. 37. pp. 125-144.

Schmidt, P. and Phillips, P.C.B. (1992). LM Test for a Unit Root in the Presence of Deterministic Trends. In: Oxford Bulletin of Economics and Statistics, Vol. 54, No. 3, pp. 257-287.

Serrano Sanz, J.M. (1999). Sector Público. Cap. 13. In: J.L. Garcia (dir): Lecciones de Economía Española. Madrid, Ed. Civitas, $4^{\mathrm{a}}$ ed.

Tridimas, G. (1992). Budgetary Deficits and Government Expenditure Growth: Toward a More Accurate Empirical Especification. In: Public Finance Quarterly, Vol. 20, No. 3, p. 275-297.

Yay, T. and Tastan, H (2009). Growth of Public Expenditures in Turkey during the 1950-2004 Period: an Econometric Analysis. In: Romanian Journal of Economic Forecasting, No. 4, pp. 101-118

Zivot, E. and Andrews, K. (1992). Further Evidence On The Great Crash, The Oil Price Shock, and The Unit Root Hypothesis. In: Journal of Business and Economic Statistics, Vol. 10, No. 10 , pp. 251-70. 


\section{APPENDIX}

\section{Graphs of the six variables}
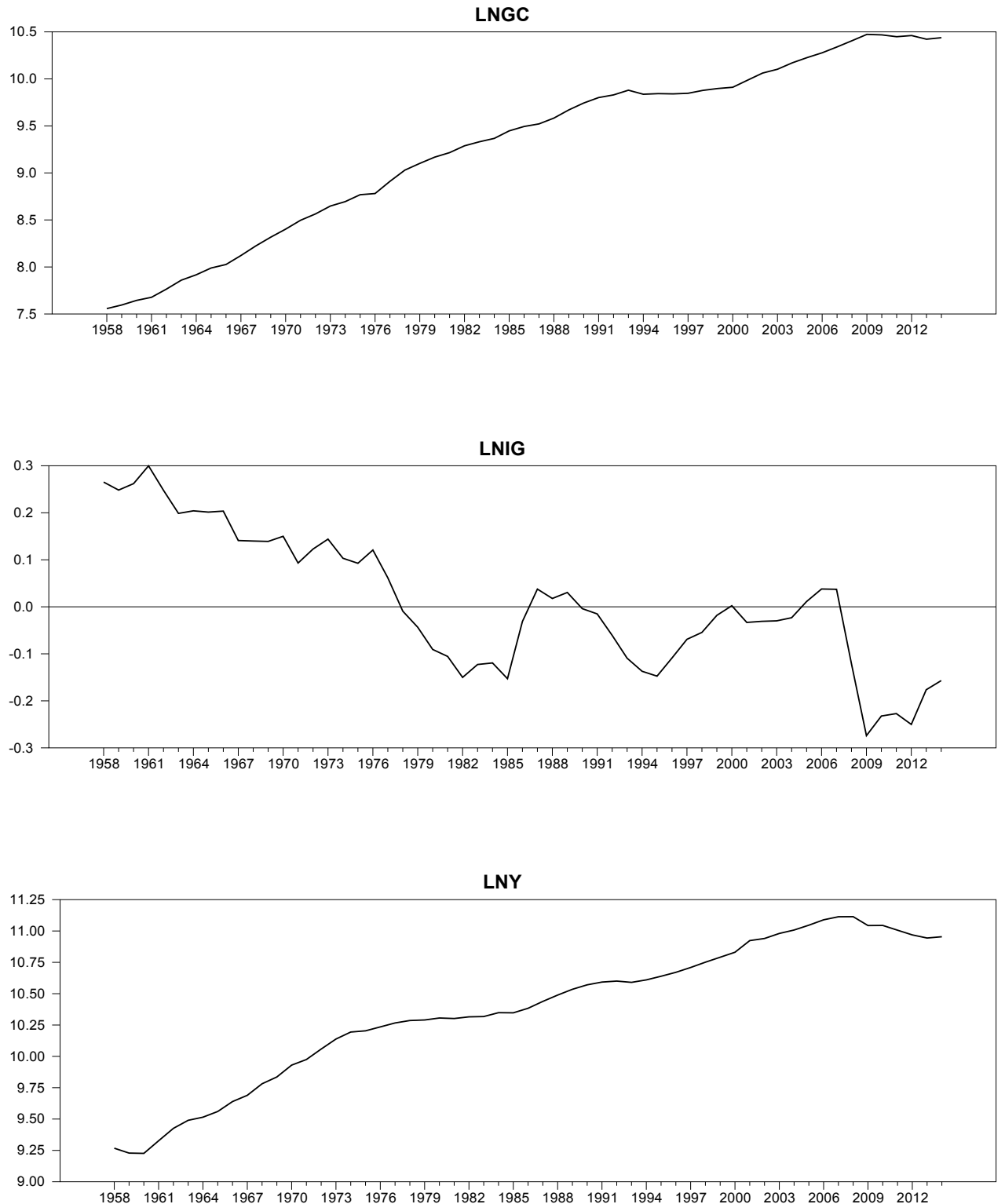

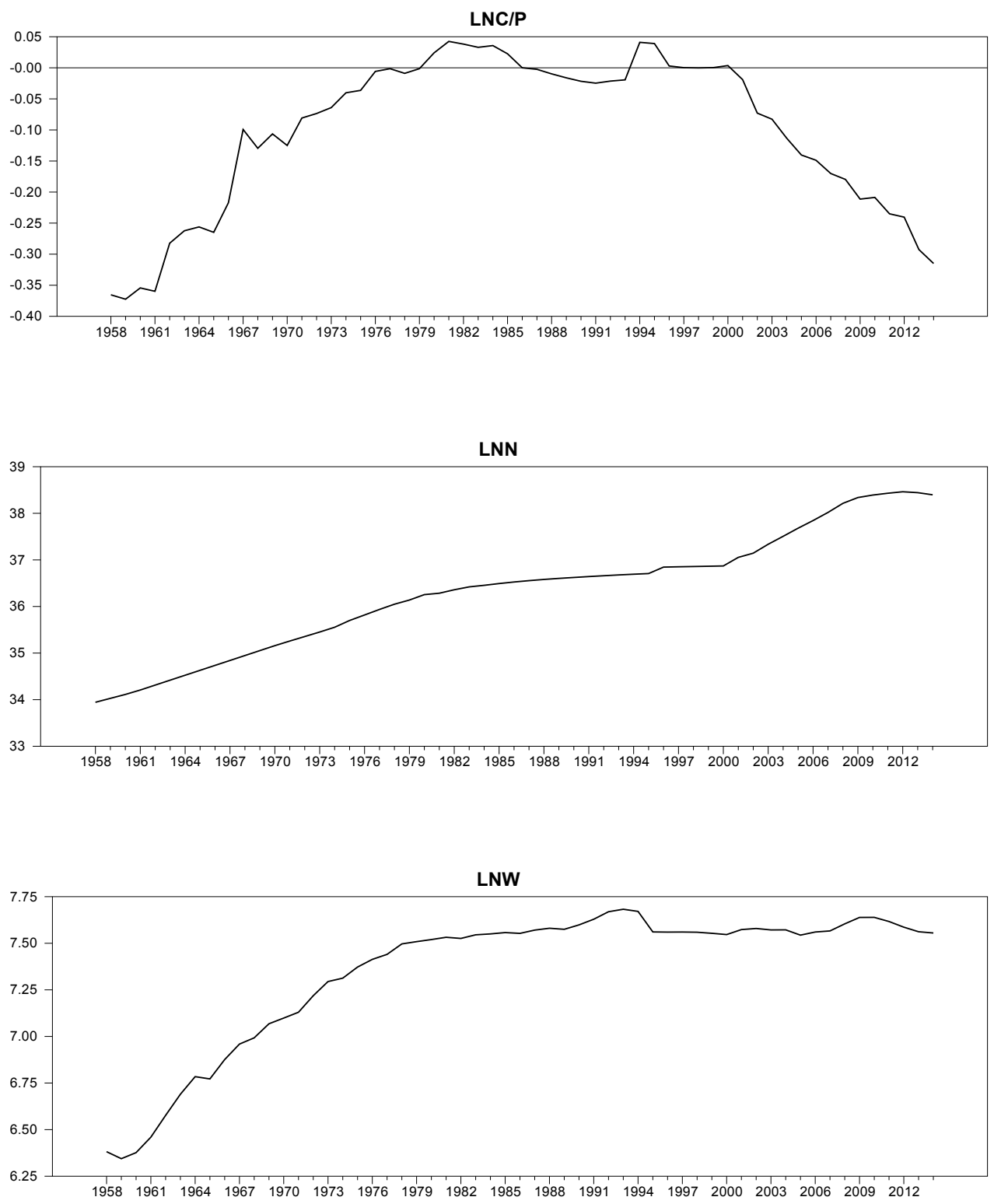

Source: Author's elaboration 
